\title{
KARINIO VEIKSNIO REIKŠMĖ BALTIJOS ŠALIŲ SĄJUNGOS KŪRIMUI
}

\author{
Egidijus Papečkys
}

\section{IVADAS}

Pirmasis pasaulinis karas ne vienai mažesnei Europos tautai sudarè sąlygas atgauti ar igyti nepriklausomybę. Per visą žemyną nuvilnijusi nacionalinio pakilimo banga lèmé, kad atkurtos ar naujai ịkurtos valstybès formavosi tautiniu principu. Labai greitai paaiškejjo, kad buvusios imperijos nèra linkusios lengvai atsisakyti savo prarastų kraštų. Tai užprogramavo netolimos ateities geopolitinę krizę, pasibaigusią dar vienu pasauliniu karu. Po šio karo „geležinė uždanga“, ilgiems šaltojo karo metams pasauli padalijo ị dvi priešiškos ideologijos puses.

Kaip pastebejjo prof. dr. Zenonas Butkus, Baltijos valstybėms šiandien nebereikia karštligiškai ieškoti naujų karinių ar politinių sąjungos formų, o galima atsidèti nuosekliam ekonominių, kultūrinių, visuomeninių ryšių stiprinimui ${ }^{1}$. Visiškai kitokia padètis buvo tarpukariu.

Trys Baltijos šalys - Lietuva, Latvija ir Estija, kartais dar vadinamos mažosiomis Baltijos šalimis, - grèsmę savo nepriklausomybei pajuto vos tik ją paskelbusios. Visai Europai grasino iš Rusijos kilęs bolševikinis tvanas, o Baltijos šalims pavojų dar kèlè ir „baltieji“ rusai, ir neskubanti pasitraukti iš okupuotų kraštų Vokietijos kariuomenè. Vèliau iki pat okupacijos grèsmę kèlè galima Sovietų Sąjungos ir Vokietijos, o Lietuvai - ir Lenkijos agresija. Désninga, kad Baltijos šalyse buvo svarstoma galimybė susiburti draugèn. Ilgas ir sudètingas sąungos kūrimo procesas baigèsi 1934 m., Lietuvai, Latvijai ir Estijai sudarius Baltijos antantès sutartị. Tačiau ji neturejo ịprasto tokio tipo sutartims karinès sąjungos komponento. Tačiau karinis veiksnys buvo viena iš sudedamųjų Baltijos sąjungos kūrimo proceso dalių.

\footnotetext{
${ }^{1}$ Butkus Z., Vokietijos ir sovietu politikos poveikis Baltijos sajungos kūrimui 1919-1940 metais. Lietuvos istorijos studijos, Vilnius, 2007, t. 20, p. 21.
} 
Šio darbo tikslas - išnagrinèti karinio veiksnio reikšmę Baltijos sajungos kūrimui. Karinis veiksnys šiuo konkrečiu atveju turètų būti suprantamas kaip išorinių karinių pajègų ịsiveržimo grèsmè, vidinis Baltijos šalių poreikis ir galimybès kartu šiai grèsmei pasipriešinti ar atgrasinti agresorių.

Uždaviniai: įvertinti karinio ịsiveržimo grèsmę; ịvertinti ir palyginti Baltijos šalių ir galimų agresorių, Vokietijos ir SSRS, karinị potencialą; išnagrinèti Lietuvos, Latvijos ir Estijos karinio bendradarbiavimo ir galimų bendrų karinių veiksmų galimybes; ịvertinti karinio veiksnio reikšmę Baltijos šalių sąjungos kūrimui. Chronologinès ribos - 1920-1940 m. Karinė galia buvo vienintelè politinè priemonè, nepanaudota siekiant išvengti okupacijos arba sumažinti jos poveikį. Todèl plačiausiai bus nagrinejjamas 1939 m. rugsèjo-1940 m. birželio laikotarpis.

Baltijos šalių tarpusavio santykiams, Baltijos antantès ịkūrimui ir jos veiklos istorijai skirta daug solidžių ir išsamių darbų². Ypač vertingi - prof. Zenono Butkaus parengtas dokumentų rinkinys „Baltijos vienybès idejja“3 ir V. Žalio „Diplomatijos istorija“4. Prof. Z. Butkus taip pat nagrinejo Vokietijos ir sovietų politikos poveikị kuriant Baltijos sąjungą Tačiau kariniai tokios sąjungos aspektai mažai tyrinėti, nors retas istorikas išvengė vienaip ar kitaip jos nepaminèjęs. Būtų galima paminèti ir dr. V. Žalio darbą, kuriame aptartas karinis bendradarbiavimas Baltijos antantès sistemoje gana trumpu, tačiau pačiu kritiškiausiu laikotarpiu 1939-1940 m. ${ }^{6}$ Lietuvoje tradiciškai vengiama nagrinèti ši klausimą - kariniam veiksniui skiriamas vos vienas kitas sakinys. Pvz., prof. dr. Z. Butkus Baltijos šalių mėginimus tartis karinio bendradarbiavimo klausimais apibūdino kaip nedrąsius, teigdamas, kad „pačios Baltijos šalys neįstengé susitarti dèl karinio bendradarbiavimo, pavyzdžiui, nesutaré, kokios strateginès linijos labiausiai turès büti ginamos“" . Dr. Algimantas Kasparavičius

\footnotetext{
2 Žr.: Butkus Z., Vokietijos ir sovietu politikos poveikis..., p. 22-23.

${ }^{3}$ Butkus Z., Baltijos valstybiu vienybes ideja ir praktika 1918-1940 metais, dokumentu rinkinys, Vilnius, 2008.

4 Žalys V., Lietuvos diplomatijos istorija (1925-1940), t. I, Vilnius, 2007.

${ }^{5}$ Butkus Z., Vokietijos ir sovietu politikos poveikis..., p. 21-41.

${ }^{6}$ Žalys V., Dèl karinio bendradarbiavimo Baltijos Antantès sistemoje (1939-1940 m.) // Lietuvos istorijos metraštis, 1988 metai, Vilnius, 1989, p. 59-78.

${ }^{7}$ Butkus Z., Vokietijos ir sovietu politikos poveikis..., p. 37-38.
} 
mano, jog „reikia sutikti su ne karta istoriografijoje minèta nuomone, kad Baltijos Antante galejo gerokai sustiprinti savo tarptautine padeti, suburdama savo militarines pajégas $i$ vieninga kumšti ir gilindama tarpusavio politine integracija" "8. Baigiant rengti straipsnị sulaukta dr. V. Jokubausko disertacijos, kurioje itin išsamiai ir brandžiai tyrinètas ir karinis Baltijos šalių potencialas 9 .

Dar mažiau Lietuvoje žinoma apie Latvijos ir Estijos kariuomenes. Išeivijos darbai (dr. E. Andersono, dr. V. Statkaus) jau nebeatitinka šiandienos reikalavimų ir galimybių, o naujų darbų labai trūksta. Pvz., V. Statkus pateikè klaidingų duomenų tiek apie Lietuvos kariuomenės ginkluotę, tiek apie jos organizaciją. E. Andersono pateikti duomenys apie Lietuvos, Latvijos ir Estijos kariuomenių ginkluotę yra itin netikslūs ir prieštarin$\mathrm{gi}^{10}$. Gaila, tačiau daugelis šiandienos istorikų nekritiškai remiasi būtent tais pačiais paminètais išeivijos autoriais. Sunkiai ịveikiamas ir kalbos barjeras, nes dauguma latvių ir estų darbų nèra išversti ị lietuvių ar anglụ kalbas. Minètini dr. Salo Urmo, kitų Latvijos ir Estijos istorikų darbai ${ }^{11}$.

Dar daugiau svarbios informacijos randame šio laikotarpio kariuomenès ir politikos veikèjų atsiminimuose. Pvz., buvęs kariuomenès vadas S. Raštikis nuolat teigia seniai suvokęs Baltijos sąjungos svarbą ir daręs žygių tokiai sąjungai sudaryti, kartu skundžiasi negavęs tam prezidento A. Smetonos pritarimo. Be abejo, būtina priminti kito iškilaus amžininko, karinio ir politinio veikejjo, diplomato K. Škirpos požiūrị ị šią problemą:

\footnotetext{
${ }^{8}$ Kasparavičius A., Lietuva 1938-1939 m. Neutraliteto iliuzijos, Vilnius, 2010, p. 252.

${ }^{9}$ Jokubauskas V., Lietuvos karine doktrina ir jos realizavimas 1923-1940 m. šiaurès rytu Baltijos regiono šalių kontekste, disertacija, Klaipèdos universitetas, 2013.

${ }^{10}$ Anderson E., The Military situation in the Baltic States//Baltic Defense Review, No. 6, 2001, p. 123, 131-132. Autorius pateikia neteisingus kariuomenių duomenis, visiškai neskiria, kurie kulkosvaidžiai yra lengvieji, kurie - sunkieji, painioja pabūklų tipus ir kalibrus. Pvz., jo nurodyto $38 \mathrm{~mm}$ kalibro priešlèktuvinių pabūklų, 12 svarų angliškų haubicų ir dar daug kitų nebuvo ne tik Latvijos kariuomeneje - jie aptariamuoju laikotarpiu apskritai neegzistavo. Vèlesni tyrejjai pateikia visiškai kitokius duomenis apie Latvijos kariuomenès ginkluotę ir organizaciją, paremtus archyviniais dokumentais.

${ }^{11}$ Salo U., Estimation of Security Threats and Estonian Defence Planning in the 1930s. Acta Historica Tallinnensia, 2008, Nr. 12, p. 35-74; Salo U.,Eesti kaitseväe valmisolek sõjaks ja vastupanuvõimalused 1939. aastal (magistro darbas), Tartu, 2005; Kuzmins V., Latvijas bruñoto spēku mobilizācijas un aizsardzības plāni 1939. gada beigās - 1940. gada sākumā // Militārais apskats, 2009, Nr. 3/4, p. 49-60.
} 
„Valstybès saugumui užtikrinti Škirpa siūle karinị bendradarbiavimą ir su mažosiomis valstybèmis - savo iniciatyva paruoše Lietuvos, Latvijos ir Estijos „neutraliteto gynimo sutarties projekta. “12 Kaip ir visi K. Škirpos pasiūlymai, šis buvo itin kategoriškas: „Projekte trys Baltijos valstybès turëjo pasižadèti „ju pareikšta griežta neutraliteta ginti visomis priemonèmis ir padèti viena kitai ginkluota pajèga, jei kuri iš susitariančiu šaliu bütų kieno nors užpulta. "Lietuvos, Latvijos, Estijos karinèms vadovybèms pavesta neatidèliotinai paruošti „Neutraliteto gynimo plana ““..13

Be abejo, K. Škirpa buvo itin profesionalus aukšto rango karininkas. Tačiau nekritiškas jo požiūrio vertinimas atitinkamai suponuoja daromų išvadų neobjektyvumą. Kaip ir kiekvienas išeivijoje atsiminimus rašęs karinis ir politinis veikejjas, K. Škirpa buvo priverstas gyventi ir sau pačiam keliamu klausimu, ar teisingai buvo pasielgta nepasipriešinus ginklu sovietinei okupacijai.

Vertinga tyrimui 1923 m. lapkričio 1 d. sudaryta dvišalè Latvijos ir Estijos (Tartu) karinè sąjunga. Šios sutarties ịgyvendinimas atskleidè daugybę sunkumų ir trūkumų ${ }^{14}$. Spręsti tokias pat problemas ir susidurti su tokiais pat trūkumais būtų tekę ir Baltijos antantės šalims, sudariusioms ir karinę sutartị. Nors tiek laikotarpis, tiek aplinkybès buvo visiškai kitos, labai vertinga NATO patirtis šaltojo karo metais. Ji taip pat atskleidžia sunkumus ir prieštaravimus, kurių neišvengiamai būtų kilę sudarius karinę ir politinę Baltijos šalių sąjungą. Tiesa, NATO patirtis nagrinejjama tik specialioje karinèje literatūroje, kol kas nedominančioje tarpukario ivykius tiriančių istorikų. Autorius pasinaudojo galimybe su šia patirtimi susipažinti bendraudamas su NATO kariuomenių veteranais, ejusiais ivairaus lygio pareigas, dalyvavusiais įvairiose bendrose pratybose, jas planuojant ir kitoje veikloje.

Kitas svarbus šaltinis - įvairių šalių žvalgybų aptariamojo laikotarpio dokumentai. Šie dokumentai labai dažnai istorikų vertinami nekritiškai. Būtina pažymėti, kad tokią ano meto žvalgybinę informaciją sunku vertinti, nepalyginus jos turinio su vèlesniais realiais ịvykiais ar kitais šal-

\footnotetext{
12 Vašcova Ž., Vienas prieš daugumą. Kazio Škirpos kurta saugios Lietuvos koncepcija // Darbai ir dienos, Kaunas, 2002, t. 30.

${ }^{13}$ Vašcova Ž., Vienas prieš daugumą...

${ }^{14}$ Ильмярв М., Безмолвная капитуляция..., с. 240.
} 
tiniais. Žvalgybos dokumentuose, ypač agentūriniuose pranešimuose, dažnai pateikiama klaidinga informacija, kurios jos užfiksavimo laikotarpiu nebuvo galimybès patikrinti. Ypač sunku vertinti sovietinius dokumentus. Dažniausiai jie yra pavieniai, o ne vienas kitą papildančių dokumentų visuma. Neretai juose pateikiama ne faktiné, o to meto vadovybès pageidaujama informacija. Be to, niekada negalima būti tikriems, ar šie dokumentai yra tikri, ar nėra „sukurpti“ siekiant kokių nors šiandieninių tikslų. Paminètinas išslaptintų Rusijos Federacijos užsienio žvalgybos dokumentų rinkinys ${ }^{15}$, kuriame labiau siekiama išaukštinti sovietų žvalgybos pasiekimus bei sumenkinti Baltijos šalių vadovus ir diplomatus, nei pateikti istorijos tyrimams naudingos medžiagos.

Straipsnyje nèra kuriama kokia nors alternatyvi istorija - „kas būtų, jeigu būtų“. Baltijos šalių kariuomenès buvo dislokuotos ir galejjo veikti konkrečioje teritorijoje. Jos disponavo konkrečiomis pajėgomis, vadovavosi konkrečiais karybos principais ir dėsniais. Pvz., pèstininkų divizijai pervežti reikejjo tam tikro geležinkelio riedmenų ir sąstatų kiekio. Pėstininkai, kavalerija ir tankai judejjo nustatytu greičiu ir t. t. Ne viskas, kas užfiksuota to meto Lietuvos ir kitų Baltijos šalių ar jų potencialių priešininkių kariuomenių dokumentuose, yra teisinga ir neginčytina. Tačiau toje pačioje teritorijoje ir tokiomis pat ar panašiomis sąlygomis vykę karo veiksmai leidžia verifikuoti tarpukario dokumentuose užfiksuotas aplinkybes. Pvz., sovietų kariuomenès veiksmų Lenkijoje, ypač Vilniaus krašte, 1939 m. rudenị analizè padeda ịvertinti Lietuvos kariuomenès pajègumą pasipriešinti 1940 m. birželį, sovietų kariuomenès puolimas Estijos šiaurès vakaruose 1944 m. - Estijos tarpukario gynybos planus ir t. t. Išsamesni Baltijos šalių ginkluotųjų pajègų tyrimai įvairiais aspektais, taip pat ir karo pramonès, leidžia kitaip vertinti to meto politinius sprendimus ir ìvykius. Deja, kol kas išsamiai išnagrinèti karinị veiksnị nèra galimybès ir dèl objektyvių duomenų trūkumo.

\footnotetext{
${ }^{15}$ Прибалтика и геополитика, 1935-1945 г2. Рассекреченные документы службы внешней разведки Российской Федерации, Москва, 2009.
} 


\section{Prielaidos ir trukdžiai kurti Baltijos sąjungą}

Dar tebegriaudint Didžiojo karo kanonadai Baltijos šalyse pradejo kaltis pirmieji nepriklausomybès daigai. Beveik nuo pat pirmų nepriklausomybès žingsnių imta svarstyti Baltijos šalių sąjungos klausimą. Šiuose svarstymuose ekonominis ir karinis veiksniai igijo vienodą svarbą. $1918 \mathrm{~m}$. leidinyje Revue Baltique Nr. 3-4 (lapkritis-gruodis) buvo publikuotas straipsnis Baltijos lyga. Straipsnio, pasirašyto inicialais K. R. P., autorystė neabejotinai priskiriama būsimam Estijos užsienio reikalų ministrui Kareliui Robertui Pustai ${ }^{16}$. Pirmasis šiai lygai keliamas uždavinys buvo karinis: "Lyga išnagrinès ir sudarys bendra gynybos sistemą. " 17 Tik tokiu būdu galès būti pasiektas pagrindinis Baltijos lygos tikslas - „laisvų mainu ir tarptautines prekybos garantija" ${ }^{18}$.

1919 m. kovo 1 d. Kaune buvo sudaryta Lietuvos ir Latvijos sutartis dèl 5 mln. markių paskolos Latvijai ir dèl ypatingų teisių suteikimo Lietuvai naudotis Liepojos uostu. Daugiau nei pusejje iš dvylikos sutarties straipsnių minima kariuomenė arba „karo medžiaga“. Lietuvos kariuomenei suteikiama neribota teisè laikyti Latvijos teritorijoje „reikiamas ginkluotas pajeggas“, o 11-ame str. susitariama dèl abiejų šalių bendradarbiavimo dalyvaujant kovos su bolševikais veiksmuose ${ }^{19}$.

Vis dèlto būta bendro Baltijos šalių karinių pajègų veikimo. Pvz., 1919 m. spalị bermontininkams puolant Latvijos kariuomenę, mūšiuose dalyvavo ir estų kariai. „Rygos pozicija padejo saugoti dar du estu gerai ginkluoti šarvuoti traukiniai<...> "20 Estų šarvuotas traukinys palaikè vieno 8-ojo latvių pėstininkų pulko bataliono puolimą per Rygos geležinkelio tiltą. Beje, čia pat paminima ir bene viena pirmųjų karinio bendradarbiavimo problemų - „po keliu dienu, latviams su estais nesusitarus dèl kompensacijos didumo, jie grǐžo ị Estiją"21.

Neretai priekaištaujama Lietuvai, kad ji lemiamą akimirką, kai grèsė

\footnotetext{
${ }^{16}$ Butkus Z., Baltijos valstybiu vienybès ideja .., p. 93-95.

${ }^{17}$ Ten pat, p. 94.

${ }^{18}$ Ten pat, p. 95.

${ }^{19}$ Ten pat, p. 101-102.

${ }^{20}$ Latvių nepriklausomybès karas // Mūsų žinynas, 1930, p. 54.

${ }^{21}$ Ten pat, p. 55.
} 
pavojus Rygai, nepadejo Latvijai kovoti su bermontininkais. Neatmestini istoriografijoje išnagrinèti motyvai. Tačiau yra ir kitų priežasčių, paaiškinančių tokią Lietuvos poziciją. Pirmoji - agresyvūs Lenkijos ketinimai. Spalio 14 d. laikinasis Lietuvos Taikos delegacijos pirmininkas T. Naruševičius rašè ministrui pirmininkui ir užsienio reikalų ministrui: „2. Estai ir latviai kreipesi su užklausimu, ar negalètume mes atidengti priešais Vokiečius fronto ir iš užpakalio atkirsti Fon der Goltz'o armijai susisiekima su Vokietija. Nežinodamas tikro padejjimo Lietuvoj, žinoma, jokio atsakymo negalejjau duoti, bet pabrèžiau, kad pirma išlyga turètų būti užtikrinimas Talkininkų, kad Lenkai neužpultu ant Lietuvos iš užpakalio. " 22

Prof. Z. Butkus atkreipè dèmesị, kad spalio $12 \mathrm{~d}$. buvo gautas Didžiosios Britanijos misijos Lietuvoje vadovo plk. Rowano Robinsono perduotas J. Pilsudskio patikinimas, kad Lenkijos kariuomené neperžengs demarkacijos linijos su Lietuva, kol vyks kovos su bermontininkais ${ }^{23}$. Deja, Lenkija ne kartą iki tol ir vèliau informavo apie vienus ar kitus savo veiksmus, tačiau ịsipareigojimų nevykdè. 1919 m. rugpjūti išaiškintas lenkų pogrindinès POW organizacijos rengtas sukilimas Kaune buvo itin akivaizdus agresyvių Lenkijos kèslų rodiklis. Tuo metu prie demarkacijos linijos vyko nuolatiniai Lietuvos ir Lenkijos kariuomenių dalinių susirèmimai. Tokie abipusiai puolimai vyko ir spalio $12 \mathrm{~d} .{ }^{24}$ Keletu sakinių aptarti visas Lietuvos ir Lenkijos santykių aplinkybes nèra galimybių. Tačiau galima teigti, kad Lietuva turejo rimtą pagrindą neskubèti atsakyti ì pagalbos prašymą - jai grèsè realus Lenkijos ginkluotụjų pajègų smūgis ị nugarą. Toks smūgis Lietuvai galejo reikšti visišką valstybingumo praradimą, o tautai - asimiliaciją ir nutautinimą.

Pažymėtina, kad istoriografijoje susiklostė praktika bermontiadą Lietuvoje vertinti vadovaujantis vien lietuviškais, dažnai antriniais, šališkais ir kritikuotinais, šaltiniais. Toks vienpusis požiūris trukdo objektyviai įvertinti šį istorijos laikotarpị ir suformuluoti pagrịstas išvadas. Pvz., Rusijos savanoriškosios Šiaurès Vakarų armijos istoriografijoje teigiama, kad Latvija pagalbos ieškojo ir Lenkijoje. Latvijos pasiuntiniams atvykus

\footnotetext{
22 Butkus Z., Baltijos valstybiu vienybès idëja..., dok. Nr. 24, p. 143.

${ }^{23}$ Lietuvos užsienio politikos dokumentai 1918-1940 m., p. 315.

${ }^{24}$ Lesčius V., Lietuvos ir Lenkijos karinis konfliktas dèl Seinų krašto 1919 m. // Karo archyvas, t. XVIII, Vilnius, 2003, p. 187.
} 
i Varšuvą, čia atvyko ir P. Bermonto-Avalovo pasiuntiniai - kunigaikštis Kropotkinas ir grafas Borchas. Jie siekè, kad Lenkija nesikištų, o už tai „kilniaširdiškai“ jai pažadèjo visą pietinę Lietuvos dalị. Teigiama, kad Bermontui-Avalovui nepagrịstą nerimą kèlè Lietuvos kariuomenès telkimas prie pietinių Lietuvos sienų, rengiantis priešintis Lenkijos keliamai grèsmei $^{25}$. Žinoma, ši ir kitus rusiškus šaltinius būtina nuodugniau tirti, analizuoti ir verifikuoti. Pažymėtina, kad ir Latvijos kariuomenès karių veiksmai Lietuvos kariuomenès atžvilgiu ne visada buvo sąžiningi ir nuoširdūs. Pvz., jau 1919 m. vasarą ị Latviją buvo išsiųstas Lenkijos kariuo-

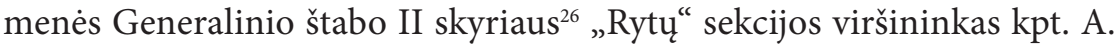
Myszkowskis. Visą savo tarnybos laiką jis keitèsi informacija su Latvijos kariuomenès Vyriausiojo vado štabu ir apie Lietuvą. O tarp Latvijos ir Lietuvos kolegų iki pat $1928 \mathrm{~m}$. nevyko jokio konkretesnio bendravimo ${ }^{27}$.

Antroji svarbi, tačiau istoriografijoje nenagrinèta praktinè aplinkybė - aptariamų kariuomenių pajègos, jų išdėstymas ir komunikacijų linijos. Bermonto-Avalovo pajègos buvo dislokuotos tarp Lietuvos ir Latvijos kariuomenių. Tad visos komunikacijos buvo bermontininkų kontroliuojamos. Tarp Estijos ir Latvijos pajėgų bermontininkų dalinių nebuvo, komunikacijos buvo latvių ir estų rankose. Todẻl keturi Estijos šarvuoti traukiniai, iki tol rėmę Rusijos savanoriškosios Šiaurès Vakarų armijos puolimą prieš bolševikus, 1919 m. spalio $10 \mathrm{~d}$. kartu su Didžiosios Britanijos karo laivais, taip pat rėmusiais ugnimi Šiaurès Vakarų armijos puolimą, niekieno netrukdomi pasiekè Rygą ${ }^{28}$. Taigi, Lietuvos kariuomenei būtų tekę jèga „prasimušti“ pro gausias bermontininkų pajègas. Kariniu požiūriu toks žygis buvo neįmanomas dẻl bermontininkų stiprumo ${ }^{29}$, di-

\footnotetext{
${ }^{25}$ Plačiau: Белая борьба на СевероЗападе России, Москва, 2003, с. 158, 159.

${ }^{26}$ II skyrius vykdė karinès žvalgybos ir kontržvalgybos funkcijas (aut. past.).

${ }^{27}$ Plačiau: Jēkabsons Ē., Zarys współpracy Łotewskiego i Polskiego wywiadu wojskowego 1919-1939 // Studia i materiały do historii wojskowości, Białystok, 2007, t. XLIV, s. 279-301.

${ }^{28}$ Белая борьба на Северо-Западе России..., с. 132.

${ }^{29} \mathrm{Kol}$ kas Lietuvos istoriografijoje nèra tikslios informacijos apie Lietuvos kariuomenès ir bermontininkų Lietuvoje pajègas aptariamuoju laikotarpiu, nepateiktas jų kiekybinis ir kokybinis įvertinimas sąlyčio zonoje, neįvertintos jų galimybės pritraukti rezervus ir kt., pasitenkinta tik abstrakčiais vertinimais arba nepagrịstais skaičiais (ypač kalbant apie bermontininkus).
} 
delio atstumo iki Rygos ir mažo Lietuvos kariuomenès judejjimo greičio ${ }^{30}$. Visos šios trys aplinkybės buvo vienodai svarbios ir neįveikiamos. Pulti bermontininkų pajègas Lietuvoje taip pat nebuvo prasmès, kadangi tai niekaip nebūtų susilpninę Rygą puolančių pajėgų.

1920 m. Baltijos ir kitoms regiono šalims sudarius taikos sutartis su Sovietų Rusija, baigèsi „jègos“ laikotarpis. Nusistovejus taikai ir klaidingai manant, kad Antantės šalys, o vèliau - Tautų Sąjunga, yra garantas, galintis užtikrinti taikų sambūvị Europoje (Tautų Sąjunga iš esmès tam ir buvo sukurta), karinio veiksnio reikšmė gerokai sumažejo. Versalio sutartimi Vokietijos ginkluotosios pajègos buvo apribotos ir nekèle jokio realaus pavojaus. Tačiau politinè Vokietijos ittaka išliko didelè. Ir Lietuvai teko pripažinti ginkluoto susidūrimo Klaipèdoje ir Klaipèdos krašte galimybę. Buvo aišku, kad tektų susidurti ne tik su vietos gyventojų organizuotais būriais, bet ir su iš Vokietijos atsiųstomis gausiomis nereguliariomis pajègomis. Todèl Lietuvos kariuomenès vadovybẻ atitinkamai dislokavo savo pajègas ir planavo karinius veiksmus. $1933 \mathrm{~m}$. nacionalsocialistams stojus prie valdžios vairo ir atkūrus ginkluotąsias pajègas, užpuolimo grèsmè kilo ir kitoms Baltijos valstybėms. Pasipriešinti tokioms didelėms šalims, valdomoms totalitarinių režimų ir nuolat didinančioms savo karinę galią, be pagalbininkų nẻ viena iš trijų Baltijos šalių negalèjo. Todẻl Lietuvos, Latvijos ir Estijos vienybès idejja tvyrojo ore, o tokios sąjungos nauda atrodè gana apčiuopiama. Daugiau ir didesnių šalių apimančio Rytų Europos bloko ar, tarkim, Lenkijos, Lietuvos, Latvijos, Estijos ir Suomijos sąjunga žadejo ir daugiau privalumų. Imperialistiniai, ekspansiniai Lenkijos siekiai užkirto kelius tokiam didesniam Rytų Europos šalių blokui susikurti.

Turime pripažinti, kad Lietuva, Latvija ir Estija pavojų savo nepriklausomybei matè žvelgdamos skirtingomis kryptimis. Didžiausią grèsmę Lietuvai kèlè Lenkija ir, kiek vèliau, Vokietija, o Estijai ir Latvijai - Sovietų Sąunga. Pvz., 1936 m. Estijos kariuomenès vadas gen. J. Laidoneris SSRS ir Vokietijos puolimo tikimybę ịvertino santykiu 12:1². O Lietuva,

\footnotetext{
${ }^{30}$ Dèl didelio atstumo pajègas buvo galima greitai permesti ir aprūpinti tik geležinkeliu. Kadangi jị kontroliavo bermontininkai, Lietuvos pajègos būtų priverstos judèti pèsčiomis, kovodamos su bermontininkų pasipriešinimu.

${ }^{31}$ Ильмярв М., Безмолвная капитуляция. Внешняя политика Эстонии, Латвии и Литвы между двумя войнами и утрата независимости, Москва, 2012, с. 228.
} 
priešingai, iš Sovietų Sąjungos tikejjosi pagalbos. Be to, ilgą laiką ginkluotos agresijos grèsmė buvo itin maža. Todèl samprotavimai iš 1939-1940 m. perspektyvos apie Baltijos šalių nesuvokimą ar nenorą burtis ị politinę ir karinę sąjungą, nukreiptą prieš sovietus, nevisiškai teisingi. Lietuvos ịsijungimas ị tokią sąungą galejjo tik komplikuoti Latvijos ir Estijos santykius su kaimyninemis valstybemis ir neduoti joms jokios politinès ar ekonominès naudos. $1935 \mathrm{~m}$. atsisakiusi priimti S. Raštiki, „Estijos karinè vadovybè užtikrino Varšuvą, kad Estijos ginkluotosios pajëgos neiškeis patikrintos draugystès su Lenkija ị pasiūlytą problematišką Lietuvos draugystę “32. Lietuvai Sovietų Sąjungos palaikymas tarptautinejje arenoje, kurio ji tikejosi, buvo nepalyginamai svaresnis už Latvijos ir Estijos, o vis stiprejanti Raudonoji armija Lenkijos kariuomenès Generaliniam štabui kèlè nerimą, kurio nekèlè nei latvių, nei estų kariuomenès.

Būta ir palankių aplinkybių trijų Baltijos valstybių sajungai sudaryti. Pirmiausia, Lietuvą, Latviją ir Estiją siejo bendra istorija. Antra, trys mažytės šalys glaudèsi viena šalia kitos labai nedidelèje teritorijoje. Trečia, jos neturèjo viena kitai neišsprendžiamų teritorinių, tautinių ar ekonominių pretenzijų. Ketvirta, visos trys buvo labai panašios, ne viena iš jų negalèjo tikètis siekti akivaizdaus lyderio pozicijų arba iggyti didesnę ịtaką nei kitos. Šios šalys turejjo galimybę suderintais veiksmais tarptautinèje politikoje tapti svarbesnès ir mažiau priklausyti nuo didesniųjų kaimynių - Vokietijos, Sovietų Sajungos ir Lenkijos. Tačiau svarbus tokios galimos sąjungos tikslas 1918-1940 m. buvo ne tik tarptautinejje politikoje ịgyti didesnị svorị. Sudètingiausias Baltijos šalims pačiu kritiškiausiu metu iškilęs uždavinys - sudaryti prielaidas atsispirti Vokietijos ir Sovietų Sąungos užmačioms panaudoti galingiausią i̊rankị - ginkluotąsias pajègas - prieš Baltijos „limitrofines“valstybes.

Galbūt tai buvo galima padaryti jungtinèmis karinèmis pajègomis? Tad kiek iš tikrųjų „svèrë“ šis „militarinis“ trijų Baltijos šalių kumštis? Ar karinis veiksnys turèjo reikšmės Baltijos sąjungos egzistencijai? Ar Baltijos valstybès - Lietuva, Latvija ir Estija - disponavo ginkluotosiomis pajègomis, kurios, susijungusios ir su viena vèliava, galèjo pasipriešinti Vokietijai ir Sovietų Sąjungai ar net šioms abiem šalims vienu metu?

A. Kasparavičius teigia, jog "galima daryti išvadą, kad 1938-1939 m. Lietuvos, Latvijos ir Estijos saugumą, užsienio politikos alternatyvas

${ }^{32}$ Ильмярв М., Безмолвная капитуляция..., с. 253. 
gniužde ne vien nepalankus Vokietijos, Lenkijos ir Rusijos (SSRS) politinis balansas, bet ir pačios Baltijos Antantès vidaus problemos “"33. Iš tiesų būta ir nelauktų problemų. Lietuvos istoriografijoje nuolatos teigiamai minimas 1938 m. liepos 2 d. direktyva Nr. 102 patvirtintas Latvijos kariuomenès plano variantas „D“ (Dienvidi - „Pietūs“). Šiame plane, Vokietijai galimai užpuolus Lietuvą, numatoma organizuoti gynybos liniją palei Ventos upę $e^{34}$. Toks sprendimas buvo aiškiai prevencinis ir gynybos požiūriu palankus Latvijai, tačiau anaiptol ne draugiškas aktas Lietuvai. Nors dauguma istorikų ši planą vertina vos ne kaip ị bendrų kovos veiksmų planą, jị igyvendindama Latvija būtų ne tik užėmusi patogesnę gynybos liniją, bet jai būtų atitekusi ir dalis Šiaurès Lietuvos. Iš esmès Latvijos kariuomenè planavo įsiveržti ir užimti liniją Bartos upé-Škoda-Seda-Kuršènai-Šiauliai-Panevėžys ${ }^{35}$. Latvijoje toks planas buvo puoselejimas jau anksčiau. Tai Lietuvos kariuomenès vadovybé konstatavo vos pasibaigus Lenkijos ultimatumui: „Pasikartojo jau seniau girdèti gandai, kad latviai mūsu karo su vokiečiais ar lenkais atveju okupuos [pabraukta mano - E. P.] dali mūsų teritorijos. Latviu sienų gynimo palengvinimo sumetimais toks latviu žygis bütų logingas. $<\ldots>$ Betgi ivykdytas ir neagresingais mūsų atžvilgiu sumetimais jis galètu suardyti mūsų mobilizacijos vykdymą. Išvada: Šis klausimas turètų būti smulkiai ištirtas ir net aptartas su Latvijos kariuomenès štabu. " 36

Tai galima vertinti vienareikšmiškai: sunkiu Lietuvos Respublikai metu, vykstant kovos veiksmams su Lenkija, Vokietija arba abiem šiomis šalimis kartu, Latvijos kariuomenè be Lietuvos Respublikos sutikimo planavo ižžengti ị suverenios šalies teritoriją ir užimti sau palankią gynybai ribą, taip sutrukdydama Lietuvos kariuomenès mobilizaciją. Lietuvai patyrus pralaimejjimą ir ją okupavus, tačiau Vokietijai neplètojant puolimo ị Latviją, išlaikyti „patogią gynybai ribą“ būtų dar aktualiau. Kas lauktų šios užimtos srities, didesniems agresoriams pasidalijus Lietuvą? Ar Latvijos kariuomenè iš čia pasitrauktų?

\footnotetext{
${ }^{33}$ Kasparavičius A., Lietuva 1938-1939 m. Neutraliteto iliuzijos..., p. 252.

${ }^{34}$ Jokubauskas V., Tuščias šūvis: galimybès atremti..., p. 27.

${ }^{35}$ Kuzmins V., Latvijas brunoto speku mobilizacijas un aizsardzibas plani..., p. 50.

36 1938-04-15 Išvados iš rengto 1938.III.17/19 d. d. lenkų puolimo, LCVA, f. 929, ap. 3, b. $1022,1.6$.
} 
Bene labiausiai suinteresuota karine Baltijos valstybių sąunga buvo Lietuva. Tačiau suinteresuotumas buvo demonstruojamas itin rezervuotai, dažniausiai apsiribojant atskirų kariškių ir karo atašè pokalbiais. Pvz., 1936 m. sausio mèn. 25 d. LR URM Politikos departamento direktorius J. Urbšys kariuomenès II skyriaus viršininkui rašè: „Dékodama už Tamsty šio meto sausio 11 d. rašta Nr. 2536, Užsieniu Reikalų ministerija praneša, kad ji nemato kliūčiu, kad plk. Skučas ir tolimesniuose pasikalbëjimuose palaikytu militarinès sajungos naudinguma ir reikalinguma tarp triju Baltijos valstybiu, bet nieku gyvu neužangažuojant Vyriausybę ar ir Karo Vadovybę. ${ }^{{ }^{37}}$ Lietuva buvo tokia problemiška partnerè, kad, pasak A. Kasparavičiaus, „karinis bendradarbiavimas su Lietuva Baltijos Santarvès partnerèms keltų daugiau rizikos, nei teiktų potencialios naudos" ${ }^{38}$. Todèl ir Estijos pozicija buvo akivaizdžiai priešinga. Pvz., leidinyje „XX amžius“ pasirodžius dr. B. Kazlausko straipsniui ${ }^{39}$, buvo sulaukta skubių Estijos diplomato pretenzijų: „Ponas Varma sake skaitas dabar Dr. Kazlausko knyga apie Pabaltijo Sajunga ir atkreipé mano demesị ị straipsnị apie karinę Pabaltijo Sajungą, kuris buvo tilpęs „XX amžiuje“. Jis manąs, kad tas straipsnis buvo ne vietoje, nes jis keliąs klausimus, kuriems realizuoti esa praktišku sunkenybių. Dèl to klausimo kèlimas, ypatingai prieš Laidonerio atvykima, gali sudaryti kai kokiu nereikalingu iliuziju. “"

Praejus septyniems mènesiams Estijos diplomatai savo poziciją pakeitė kardinaliai: „Š. m. kovo 30 d. buvo apsilankęs Estijos pasiuntinys. Jisai dèl santykiu su Lietuva pareiške, kad gavęs Estijos Respublikos prezidento, ministro pirmininko ir visos savo vyriausybès isakyma padaryti visa, kas tik galima, kad santykiai su Lietuva būtu galimai glaudesni, kad tuos santykius plètojant lietuviai Estijoje ir estai Lietuvoje bütu traktuojami kaip savi tautiečiai, kad tuo būdu galbūt pavyktų kai kuriais klausimais padaryti teigiama ìtaka ir trečiajam Pabaltijo Santarvés nariui ir kad toks teigiamas estu

\footnotetext{
${ }^{37}$ Butkus Z., Baltijos valstybiu vienybès ideja ir praktika 1918-1940 metais, dokumentu rinkinys, Vilnius, 2008, p. 579.

${ }^{38}$ Kasparavičius A., Lietuva 1938-1939 m. Neutraliteto iliuzijos..., p. 217.

${ }^{39}$ Kazlauskas B., Naujos nuotaikos ir Baltijos valstybių likimas. Estų-latvių gynimosi sutartis. Trijų Baltijos valstybių santarvė. Militariniai santarvininkų ryšiai nepriklausomybei ir neutralumui garantuoti // XX amžius, 1939 m. rugpjūčio 19 d., nr. 187 (939), p. 3.

${ }^{40}$ Kasparavičius A., Lietuva 1938-1939 m. Neutraliteto iliuzijos..., p. 320.
} 
politikos vadovybès nusistatymas esa jų alfa ir omega." ${ }^{41}$

Ilgą laiką tikejjusios Tautų Sąungos ir didžiųjų Europos valstybių galimybe garantuoti taiką, Baltijos šalys kartu su kitomis mažesnèmis Europos šalimis buvo įsuktos ị diskusijų apie garantijų suteikimą procesą. Didžiosioms šalims joms už nugarų tariantis dèl garantijų, agresijos ir agresoriaus apibrèžimų, vengta drąsesnių sprendimų. Be to, itin aktyviai, dažniausiai derindamos savo veiksmus, prieš kuriamą Baltijos sąjungą veike Vokietija ir Sovietų Sąjunga. Šis priešiškas veikimas yra taip išsamiai ir ne kartą nagrinètas, kad netikslinga čia to aptarti. Galiausiai pasirinktas kiekvienos atskiros šalies neutralitetas.

\section{Karinis Baltijos šalių ir galimų agresorių potencialas}

İvertinti karini šalies potencialą kiekybiškai ir kokybiškai gana sunku. Vertinant Baltijos šalių kariuomenių pajègumus teks pasinaudoti statistiniu metodu. Pirmiausia reikètų suskaičiuoti Baltijos šalių ir jų potencialių priešininkių pajègas. Beje, tokị pasiūlymą buvo pateikęs ir K. Škirpa: „Projektas numate pasikeisti visais slaptais militaristiniais daviniais apie kiekvienos susitariančiu šaliu dabartinị krašto gyvenimo parengimą. ${ }^{42} \mathrm{~Pa}-$ našų darbą - apskaičiavo Baltijos šalių karines pajègas 1939 m. rugsejjo mènesį, po mobilizacijos, - atliko minètas Estijos istorikas Salo Urmo ${ }^{43}$. Šiame darbe rasime ir didesnių ar mažesnių klaidelių, taip pat netikslumų dẻl naudotų šaltinių trūkumų, ypač latviškų ir lietuviškų, tačiau pagrindiniai skaičiai ir dydžiai yra labai vertingi. Informatyvų kariuomenès materialinio aprūpinimo ir apginklavimo vertinimą îvairiais pjūviais pateike ir pagrindè dr. V. Jokubauskas. Pirma - absoliučiais skaičiais nurodytos ginkluotès ir amunicijos atsargos. Antra - kiek vidutiniškai amunicijos teko vienam šaunamajam ginklui ar artilerijos pabūklui. Trečia - kiek ginkluotès santykinai teko 1000 karių ir 10000 gyventojų. Ir

\footnotetext{
${ }^{41}$ Ten pat, p. 352.

42 Žalys V., Lietuvos neutralumas ir jo saugumo problemos 1938-1939 m. // Lituanistika, 1990, Nr. 1.

${ }^{43}$ Salo U., Eesti kaitseväe valmisolek sõjaks ja vastupanuvõimalused 1939. aastal., Tartu, 2005.
} 
šie duomenys rodo, kad visos trys Baltijos šalys daugeliu atvejų nenusileido didžiosioms valstybėms ${ }^{44}$.

Pažymėtina, kad XIX a. pab. - XX a. karo istorijoje jau neapsiribota vien gyvosios jejgos skaičiavimais. Tobulejjant taktikai ir operacijų planavimui, karinès pajègos imtos vertinti skaičiuojant kovinius dalinius ir junginius. Būtent savarankiškų junginių - divizijų ir brigadų - skaičius leidžia tiksliausiai ịvertinti kariuomenių operatyvines galimybes ${ }^{45}$.

Baltijos šalys egzistavo konkrečioje geopolitinèje erdvèje. Aptariamuoju laikotarpiu joms karinio įsiveržimo grèsmę kèlè dvi valstybès Vokietija ir Sovietų Sąunga ${ }^{46}$. Šụ abiejų valstybių karinis potencialas ir keliama grèsmė 1920-1940 m. kito labai dinamiškai ir ženkliai. Palyginkime Baltijos šalių, Sovietų Sąjungos ir Vokietijos ginkluotąsias pajègas tam tikrais laikotarpiais.

1920-1933 m. buvo pats palankiausias periodas. Potencialių agresorių ginkluotosios pajejgos buvo ribotos kiekybiškai ir kokybiškai. Tai ribojo ir karinio ịsiveržimo pavojų. Nuo 1919 iki 1933 metų 1919 m. suvaržytą Versalio sutartimi reichsverą sudarè 7 péstininkų ir 3 kavalerijos divizijos ${ }^{47}$. Vokiečių pėstininkų divizijos (7) sudarė tik 63,6 \% bendro Baltijos šalių pèstininkų divizijų (11) skaičiaus. Lietuva ribojosi su Rytų Prūsijos sritimi. Šioje nuo Vokietijos Lenkijos atskirtoje teritorijoje

\footnotetext{
${ }^{44}$ Jokubauskas V., Lietuvos karine doktrina ir jos realizavimas..., p. 159.

${ }^{45}$ Pvz., XIX a. buvo skaičiuojamas bendras karių, pèstininkų, kavalerijos ir patrankų kariuomenèje skaičius. Tobulejjant kariuomenių ginkluotei, organizacijai ir taktikai, imta skaičiuoti pasirinktus vienodos ar panašios organizacijos ir sudèties dalinius. XX a. pr., 1905 m. Rusijos-Japonijos, Pirmajame pasauliniame karuose buvo skaičiuojami pèstininkų batalionai, kavalerijos eskadronai ir artilerijos baterijos. Rusijos pilietiniame kare, dèl karių ir ginklų trūkumo nebelikus ịprastos organizacijos ir sudèties kariuomenès dalinių, vèl imti skaičiuoti „durtuvai“ ir „kardai“. Vèliau, po Pirmojo pasaulinio karo, pagrindiniu taktiniu vienetu tapo divizija. Pajejgas imta vertinti pagal jas sudarančių divizijų ir atskirų brigadų skaičių (aut. past.).

${ }^{46}$ Nepaisant įtemptų Lietuvos ir Lenkijos santykių, kalbèti apie Lenkijos keliamą karinę grèsmę Baltijos sąjungai nèra pagrindo.

${ }^{47}$ Pagal Versalio taikos sutartị Vokietijos kariuomenę (reichsverą) galèjo sudaryti ne daugiau kaip 100000 savanoriškai tarnaujančių karių, 7 pèstininkų divizijų ir 3 kavalerijos divizijos, dislokuotos nurodytose vietose, kurioms buvo uždrausta turèti sunkiosios, prieštankinès ir priešlèktuvinès artilerijos, tankų ir šarvuočių, aviacijos, specialiųjų inžinerinių dalių ir kt. (aut. past.).
} 
esančios ginkluotosios pajėgos priklausė I karinei apygardai (Wehrkreis I). Taikos metu Rytų Prūsijoje buvo dislokuotos tik dvi - 1-oji ir 11-oji $\mathrm{PD}^{48}$. Tai buvo net 5,5 karto mažiau, nei taikos metu turèjo Lietuva, Latvija ir Estija kartu. Be to, Vokietija visiškai neturejjo nei karinių lèktuvų, nei priešlèktuvinių pabūklų. Baltijos šalių karinès oro pajègos praktiškai galèjo veikti nevaržomos. Vokietijos karinès pajègos neturejjo tankų ir šarvuotų automobilių. Atsižvelgiant ị tai, kad Vokietija neturejjo tiesioginio susisiekimo su Rytų Prūsija ir bendros sienos su Latvija ir Estija ir jos galimybès permesti ị Rytų Prūsiją naujas divizijas arba vykdyti jūrų desanto operacijas buvo labai ribotos, tuo metu realaus pavojaus Vokietijos ginkluotosios pajėgos nei Lietuvai, nei tuo labiau Latvijai ir Estijai nekèlè.

Sovietinè kariuomenè šiuo laikotarpiu buvo labai menkai aprūpinta ginkluote ir karinėmis priemonėmis, prastai organizuota. Darbininkų ir valstiečių Raudonojoje armijoje ${ }^{49}$ buvo tik 49 péstininkų divizijos ${ }^{50}$. Šios divizijos ir kiti daliniai buvo dislokuoti labai plačioje teritorijoje, toli vienas nuo kito. Kariuomenė buvo ginkluota Pirmojo pasaulinio ir pilietinio karų laikų ginklais, kuriuos reikejjo taisyti, o ginkluotès kūrimo programa tik prasidejo. Pasibaigus pilietiniam karui šautuvų trūkumas buvo toks aštrus, kad 1923 m. kovo 6 d. RKP(b) CK Politinio biuro komisija patvirtino anksčiau priimtą nutarimą užsienyje pirkti 100000 šautuvų. Ir tik nesant galimybių jų i̇sigyti, numatẻ panaudoti skirtas lèšas savo pramonei kelti ${ }^{51}$. $1925 \mathrm{~m}$. rugsejji DVRA reikèjo 21605 lengvụjų kulkosvaidžių, o turẻjo tik 7500 užsienietiškų prastos kokybės ịvairių sistemų kulkosvaidžių ir nedidelę šovinių atsargą, kuri sparčiai mažejo. Perginkluoti naujais lengvaisiais kulkosvaidžiais I ir II eilès šaulių ir kavalerijos dalinius planuota iki 1928 m. pavasario ${ }^{52}$. Dar 1930 m. daugu-

${ }^{48}$ Tekste bus vartojamos ir atitinkamos santrumpos. PD - pėstininkų divizija. Kadangi sovietų ginkluotosiose pajėgose péstininkų divizijos atitikmuo buvo šaulių divizija, joms žymėti vartojama santrumpa ŠD, KD - kavalerijos divizija, péstininkų brigada - $\mathrm{PBr}$, kavalerijos brigada - KBr, kavalerijos pulkas - KP (aut. past.).

${ }^{49}$ DVRA, rus. - РККА (Рабоче-Крестьянская Красная Армия), sovietų sausumos ginkluotosios pajėgos.

${ }^{50}$ Павловский И. Г., Сухопутные войска СССР, Москва: Воениздат, 1985, с. 46.

${ }^{51}$ Советское военно-промыленное производство 1918-1926, Москва, 2005, ч. 2, с. 287.

52 Ten pat, c. 194, 502. 
moje sovietinių šaulių pulkų vos vienoje iš 9 šaulių kuopų būta lengvụjų kulkosvaidžių. Sunkiųjų kulkosvaidžių trūkumas DVRA - 10600 vnt. Rankinių granatų reikèjo 4,197 mln., turèta tik 0,2 mln. vnt. ${ }^{53}$

1923 m. trūko trečdalio vadų, ypač jaunesniųjų, arklių - 12,5\%, tačiau, svarbiausia, dèl pilietinio karo ir po jo kilusios pašarų krizès arkliai visiškai netiko naudoti kariuomenèje. Pusẻ iš 550 tūkst. sausumos pajègų karių buvo neapauti ir neparengti ${ }^{54}$. Patikrinusi sandèlius komisija nustatè, kad $50 \%$ turto (45 tūkst. vagonų!) dèl prastų saugojimo sąlygų netinkami naudoti ${ }^{55}$. Taikos metu divizijose buvo labai mažai karių $^{56}$. Šaulių divizijos buvo labai prastai apginkluotos ${ }^{57}$. RA turejjo 10 kavalerijos divizijų, 9 atskirosios kavalerijos brigadas ir 2 atsk. kavalerijos pulkus. Kavalerijoje taikos metu trūko 17,1 \% karių ir 38,7 \% arklių. Dèl šios priežasties kavalerija nebuvo pajègi ịvykdyti keliamų uždavinių ${ }^{58}$. Šarvuočių pajègos buvo drastiškai sumažintos: šarvuotųjų traukinių nuo 44 sumažejo iki 19, šarvuotųjų divizionų - nuo 10 iki 3, tankai buvo perkelti ị vieną pulką ${ }^{59}$. Buvo pradèti formuoti pirmieji mechanizuotieji daliniai. $1932 \mathrm{~m}$. buvo suformuoti pirmieji 2 mechanizuotieji korpusai, dydžiu prilygstantys divizijai. Tačiau susidurta su sunkumais mechanizuotuosius dalinius mokant, rengiant ir aprūpinant, nebūta teorinių prielaidų tokias stambias mechanizuotąsias pajègas panaudoti. Reali sovietinès kariuomenès galia, kurią galèjo sutelkti Baltijos šalių

\footnotetext{
${ }^{53}$ Ten pat, c. 194, 503.

${ }^{54}$ Реборма в Красной Армии. Документы и материаль 1923-1928, книга 1, Москва, 2006, c. $41,43,76$.

${ }^{55}$ Ten pat, p. 80. Pvz., viename sandèlyje, kuriame turejjo būti 300 šautuvų, buvo laikoma 600. Dèl šios priežasties išlinko apačioje gulejjusių šautuvų vamzdžiai ir ginklai tapo netinkami naudoti.

${ }^{56}$ Ten pat, p. 265. Taikos metu trijų tipų kadrinèse divizijose po 4554, 4674 ir 4711 karių, trijų tipų teritorinèse divizijose po 2092, 622 ir 202 karius atitinkamai.

57 Ten pat, p. 203, 204. Sovietų šaulių bataliono kulkosvaidžių kuopa turejo tik 8 kulkosvaidžius, šaulių pulkas iš viso - 24. Palyginimui - Lietuvos kariuomenèje pagal etatus buvo numatyta pèstininkų pulke turèti 36 sunkiuosius ir 54 lengvuosius kulkosvaidžius (pastarųjų sovietinejje kariuomenèje beveik nebuvo). Sovietų divizijoje buvo numatyti 25 artilerijos pabūklai, iš jų $1 / 3$ - mažo kalibro $(37 \mathrm{~mm})$ pèstininkų pabūklų. Lietuvos kariuomenèje turèta vidutiniškai 24 75-105 mm pabūklus vienai divizijai.

58 Ten pat, p. 245.

${ }^{59}$ Ten pat, p. 264.
} 
puolimui, buvo labai menka.

Padètis Vokietijoje pradejo keistis dar iki ị valdžią ateinant nacistams. Jau 1932 m. vasario 22 d. Lenkijos karo atašè Berlyne dipl. papulkininkis W. Morawskis tvirtino, kad Veimaro Respublika per 3 dienas gali mobilizuoti 300 tūkst. karių kariuomenę, susidedančią iš 21 pèstininkų ir 5 kavalerijos divizijų, ginkluotų naujausiais ginklais ir technika ${ }^{60}$.

Lenkijos žvalgybos gauti dokumentai (mobilizacijos planas Organizations-Kriegspiel, nuo $1931 \mathrm{~m}$. pervadintas ì Planstudien) jau antrojo dešimtmečio pab. - trečiojo pr. numatè mobilizuoti 21 pėstininkų ir 9 kavalerijos divizijas ${ }^{61}$. Pasirengimas karo atveju iš kiekvienos pėstininku ir kavalerijos divizijos suformuoti po 3 divizijas buvo pradètas igyvendinti $1930 \mathrm{~m}$. Tačiau ginklų turèta tik $2 / 3$ reikiamo kiekio, be to, ir tuos pačius buvo labai sunku slèpti nuo stebètojų kontrolès.

$1933 \mathrm{~m}$. Vokietijoje valdžią perèmus nacionalsocialistams, padètis pradèjo sparčiai keistis. Jau $1934 \mathrm{~m}$. lapkričio $1 \mathrm{~d}$. Vokietijos pėstininkų divizijų skaičius padidejo 3 kartus, t. y. iki 21 PD. 1935 m. kovo 16 d. ¿̇vesta visuotinė karo prievolè sudarè prielaidas sparčiam kariuomenès didinimui artimiausiu metu. $1935 \mathrm{~m}$. Versalio sutarties sąlygų suvaržytą reichsverą pakeitè vermachtas ${ }^{62}$, o Vokietija turimų pėstininkų divizijų skaičiumi Baltijos šalis jau lenkè daugiau kaip du kartus. Tačiau Rytu Prūsijoje vis dar buvo beveik 4 kartus mažiau divizijų nei Baltijos šalių kariuomenèse (1 lentelè).

\footnotetext{
${ }^{60}$ Rezmer W., Zagrożenie niemieckie w ocenach polskich władz wojskowych w pierwszej połowie lat trzydziestych XX wieku // Studia Deklaracja polsko-niemiecka o niestosowaniu przemocy, Warszawa, s. 214.

61 Ten pat, p. 213.

${ }^{62}$ Vokietijos ginkluotųų pajègų pavadinimas $1935-1945$ m. (aut. past.)
} 
Kariuomenių sudètis $1935 \mathrm{~m}^{63}$

\begin{tabular}{|l|c|c|c|c|c|c|c|}
\hline & $\begin{array}{c}\text { Lietu- } \\
\text { va }\end{array}$ & $\begin{array}{c}\text { Latvi- } \\
\text { ja }\end{array}$ & Estija & $\begin{array}{c}\text { Baltijos } \\
\text { šalys kartu }\end{array}$ & $\begin{array}{c}\text { Vokie- } \\
\text { tija }\end{array}$ & $\begin{array}{c}\text { Iš jų Rytų } \\
\text { Prūsijoje }\end{array}$ & SSRS \\
\hline Pėstininkų divizijų & 3 & 4 & & 11 & 24 & 3 & 86 \\
\hline Tankų divizijų & - & - & - & - & 3 & - & - \\
\hline $\begin{array}{l}\text { Mechanizuotujų } \\
\text { korpusú }\end{array}$ & - & - & - & - & - & - & 2 \\
\hline Tankų brigadų & - & - & - & - & - & - & 6 \\
\hline Kavalerijos divizijų & - & - & - & - & 2 & - & $20^{65}$ \\
\hline Kavalerijos brigadų & $1^{66}$ & $\mathrm{x}$ & $\mathrm{x}$ & $1^{67}$ & 1 & 1 & - \\
\hline
\end{tabular}

Matome, kad šiuo laikotarpiu Vokietija nebuvo itin pranašesnè už Baltijos šalis. Sovietų kariuomenė turèjo didelę kiekybinę persvarą, tačiau ji buvo išmètyta SSRS platybèse ir tinkamai nepasirengusi. 1936 m. prasidèjęs pilietinis karas Ispanijoje atitraukè Vokietijos ir SSRS dèmesị ir didelę dalị karinių resursų.

$1938 \mathrm{~m}$. buvo itin grèsmingi dèl kilusios Miuncheno krizès. Baltijos šalys sustiprino savo ginkluotę, tačiau atotrūkis tarp jų ir Vokietijos bei SSRS pajègų nepaliaujamai didèjo (2 lentelè ).

Vokietija toliau didino savo karines pajėgas ir $1938 \mathrm{~m}$. turejo tris kartus daugiau péstininkų divizijų nei Baltijos šalys. 1938 m. kovą, kilus Vokietijos

${ }^{63}$ Lietuvos pajègu sudètis pateikta remiantis ịvairiuose LCVA fonduose saugomais duomenimis, Latvijos ir Estijos - remiantis autoriaus skaičiavimais, Vokietijos - Tessin G., Verbände und Truppen der deutschen Wehrmacht und Waffen SS im Zweiten Weltkrieg 1939-1945. Band 1-16, Osnabrück, 1996, Sovietų Sąjungos - Ленский А. Г., Сухопутные силь РККА в предвоенные годы, справочник, СПб, 2000 ir kt.

64 Mechanizuotasis korpusas dèl organizacijos ir dydžio galèjo būti prilygintas tankų divizijai (aut. past).

6515 kavalerijos ir 5 kalnų kavalerijos divizijos, 1935 m. pab. jau buvo 30 kavalerijos divizijų.

66 Formaliai abu turèti kavalerijos pulkai sudarè kavalerijos brigadą, tačiau tai tebuvo administracinis pavaldumas. Prasidejus karo veiksmams pulkai veikti turèjo atskirai ir nebūtų pavaldūs brigados vadui (aut. past.).

67 Estijos ir Latvijos ginkluotosiose pajègose buvo po $1 \mathrm{KP}$. Kadangi kavalerijos brigados tuo metu paprastai sudare 3-4 KP, bendrai Baltijos šalių kavalerija (iš viso $4 \mathrm{KP}$ ) vertintina kaip viena $\mathrm{KBr}$. 
ịsiveržimo ị Lietuvą grèsmei, Rytų Prūsijoje vis dar buvo 3 kartus mažiau péstininkų divizijų nei Lietuvoje, Latvijoje ir Estijoje kartu. Pirmieji tankai čia atsirado tik 1937-10-12, suformavus vieną tankų batalioną (I./Pz.Rgt.10 - 10-ojo tankų pulko I batalionas). Lenkijos ultimatumo metu šis batalionas baigè parengiamąsias pratybas, o kovinès parengties buvo 1938-04-01.

Sovietų pajègos itin padidejo, o ir jų apginklavimas gerokai pagerejo. Svarbiausia, kad SSRS jau turejjo didelių šarvuočių, tankų ir motorizuotụjų junginių, galinčių judèti nepalyginti greičiau už Baltijos šalių pèstininkų divizijas. Todèl sovietai galejjo pasirinktoje vietoje ir pasirinktu metu primesti mūš̌i, sutelkti gausias šarvuotas motorizuotąsias pajègas, perkirsti ar apeiti Baltijos šalių kariuomenių gynybą.

\section{Kariuomenių sudėtis $1938 \mathrm{~m}$. kovą ${ }^{68}$}

\begin{tabular}{|l|c|c|c|c|c|c|c|}
\hline & Lietuva & Latvija & Estija & $\begin{array}{c}\text { Baltijos } \\
\text { šalys } \\
\text { kartu }\end{array}$ & $\begin{array}{c}\text { Vokie- } \\
\text { tija }\end{array}$ & $\begin{array}{c}\text { Iš jų Rytų } \\
\text { Prūsijoje }\end{array}$ & SSRS \\
\hline $\begin{array}{l}\text { Pėst. ir kln. šaulių } \\
\text { divizijų }\end{array}$ & 3 & 4 & 4 & 11 & 35 & 3 & $96^{69}$ \\
\hline Mot. pejst. divizijų & - & - & - & - & 4 & - & - \\
\hline Lengvųjų divizijų & - & - & - & - & 3 & - & - \\
\hline $\begin{array}{l}\text { Kavalerijos } \\
\text { divizijų }\end{array}$ & - & - & - & - & - & - & 25 \\
\hline $\begin{array}{l}\text { Kavalerijos } \\
\text { brigadų }\end{array}$ & 1 & $\mathrm{x}$ & $\mathrm{x}$ & 1,5 & 1 & 1 & 2 \\
\hline Tankų korpusų & - & - & - & - & - & - & 4 \\
\hline Tankų divizijų & - & - & - & - & 5 & - & - \\
\hline Tankų brigadų & - & - & - & - & 1 & - & 34 \\
\hline
\end{tabular}

${ }^{68}$ Lietuvos pajègu sudetis pateikta remiantis ịvairiuose LCVA fonduose saugomais duomenimis, Latvijos ir Estijos - remiantis autoriaus skaičiavimais, Vokietijos - Tessin G., Verbände und Truppen der deutschen Wehrmacht und Waffen SS im Zweiten Weltkrieg 1939-1945. Band 1-16, Osnabrück, 1996, Sovietų Sąungos - Ленский А. Г., Сухопутные силы РККА в предвоенные годы, справочник, СПб, 2000 ir kt.

${ }^{69}$ Pagal mobilizacijos planą prasidejjus karui galèjo būti mobilizuota 170 šaulių divizijų. Žr.: Ленский А. Г., Сухопутные силы РККА в предвоенные годы, справочник, СПб, 2000, c. 193; IP. 9-10; Istorija..., c. 65. 
Kardinaliai padètis pasikeitè 1939 m. rudenị, Vokietijai ir Sovietų Sąjungai pasirašius Molotovo-Ribbentropo paktą ir mobilizavus kariuomenes. Nors Rytų Prūsija vis dar negalejo susisiekti sausuma su Vokietija, 1939 m. rugpjūti Vokietijos kariuomenè pademonstravo gebą greitai sustiprinti pajègas Rytprūsiuose, permesti ir šarvuotas motorizuotąsias pajègas. Mobilizuotos Vokietijos ir SSRS kariuomenès Baltijos šalių pajègas viršijo keletą ir keliolika kartų (3 lentelè).

1939 m. rugsëjo 1 d. ${ }^{70}$

\begin{tabular}{|l|c|c|c|c|c|c|c|}
\hline & $\begin{array}{c}\text { Lietu- } \\
\text { va }\end{array}$ & Latvija & Estija & $\begin{array}{c}\text { Baltijos } \\
\text { salys kartu }\end{array}$ & $\begin{array}{c}\text { Vokie- } \\
\text { tija }\end{array}$ & $\begin{array}{c}\text { Rytų } \\
\text { Prūsijoje }\end{array}$ & SSRS \\
\hline $\begin{array}{l}\text { Pestininkų } \\
\text { divizijų }\end{array}$ & 3 & 4 & 4 & 11 & $84^{71}$ & 8 & $173^{72}$ \\
\hline Lengvujų divizijų & - & - & - & - & 4 & - & - \\
\hline $\begin{array}{l}\text { Kavalerijos } \\
\text { divizijų }\end{array}$ & - & - & - & - & - & - & 16 \\
\hline $\begin{array}{l}\text { Kavalerijos } \\
\text { brigadų }\end{array}$ & 1 & $\mathrm{x}$ & $\mathrm{x}$ & 1,5 & 1 & 1 & - \\
\hline Tankų korpusų & - & - & - & - & - & - & 4 \\
\hline Tankų divizijų & - & - & - & - & 7 & 1 & - \\
\hline Tankų brigadų & - & - & - & - & - & - & 34 \\
\hline
\end{tabular}

Po Lenkijos sutriuškinimo prie Baltijos šalių sienų stovejjo didžiulès, visiškai mobilizuotos kariuomenès, kurioms buvo galima tikètis priešintis tik labai ribotą laiką.

Savo atsiminimuose K. Manerheimas labai aukštai įvertino galimos Baltijos sąjungos karines pajègas: „Kalbèta, kad Lietuvos ginkluotuju pa-

\footnotetext{
${ }^{70}$ Lietuvos pajegu sudetis pateikta remiantis įvairiuose LCVA fonduose saugomais duomenimis, Latvijos ir Estijos - remiantis autoriaus skaičiavimais, Vokietijos - Tessin G., Verbände und Truppen der deutschen Wehrmacht und Waffen SS im Zweiten Weltkrieg 1939-1945. Band 1-16, Osnabrück, 1996, Sovietų Sąungos - Ленский А. Г., Сухопутные силь РККА в предвоенные годь, справочник, СПб, 2000 ir kt.

71 İskaitant 4 motorizuotąsias pėstininkų divizijas.

72 Rugpjūčio 15 d. buvo 99, 173 turèjo būti rugsèjo 5-ą. Žr.: Мельтюхов М. И., Советскопольские войнь. Военно-политическое противостояние 1918-1939 г2., Москва, 2001; Int. prieiga: http://militera.lib.ru/research/meltyukhov/index.html [žr. 2012-01-22]
} 
jëgu vadas generolas Raštikis iš karto po Lenkijos užpuolimo neva pasiūle Baltijos šalims tarp savęs sudaryti karinę sajunga, bet Estija ir Latvija lyg tai atsisake iš baimes, kad Sovietu Sajunga tai priims kaip provokacija. Baltijos šaliu sajunga būtų disponavusi 20 divizijų. " 73

Deja, skaičiai rodo ką kita - visos trys Baltijos šalys nebuvo pajejgios mobilizuoti netgi 15 divizijų.

$1940 \mathrm{~m}$. birželio pradžioje Vokietijos kariuomenè visas pajègas metė prieš sąjungininkus Europoje, o SSRS sukaupe, rodos, itin galingas pajègas (4 lentelè).

4 lentele

\section{Kariuomenių sudètis $1940 \mathrm{~m}$. birželị ${ }^{74}$}

\begin{tabular}{|l|c|c|c|c|c|c|}
\hline & Lietuva & Latvija & Estija & $\begin{array}{c}\text { Baltijos } \\
\text { šalys kartu }\end{array}$ & Vokietija & SSRS \\
\hline Pėstininkų divizijų & 3 & 4 & & 11 & 107 & 161 \\
\hline Tankų divizijų & - & - & - & - & 10 & - \\
\hline Tankų brigadų & - & - & - & - & - & 32 \\
\hline Lengvųjų divizijų & - & - & - & - & 4 & - \\
\hline Kavalerijos divizijų & - & - & - & - & 1 & 20 \\
\hline Kavalerijos brigadų & 1 & $\mathrm{x}$ & $\mathrm{x}$ & 1,5 & - & - \\
\hline
\end{tabular}

Tačiau toks skaičiavimas nèra visiškai teisingas. Pvz., 1940 m. birželị, kai Sovietų Sąjungos agresyvūs veiksmai pasiekè kulminaciją, sovietai prie Baltijos šalių sienų buvo sutelkę palyginti nedidelę kariuomenę. Baltijos šalims įvykdžius mobilizaciją, skirtumas tarp visų Baltijos šalių karinių pajègų ir sovietų pajègų, sutelktų okupacijai, būtų dar mažesnis (5 lentelè).

\footnotetext{
${ }^{73}$ http://militera.lib.ru/memo/other/mannerheim/09.html

${ }^{74}$ Lietuvos pajègų sudetis pateikta remiantis ịvairiuose LCVA fonduose saugomais duomenimis, Latvijos ir Estijos - remiantis autoriaus skaičiavimais, Vokietijos - Tessin G., Verbände und Truppen der deutschen Wehrmacht und Waffen SS im Zweiten Weltkrieg 1939-1945. Band 1-16, Osnabrück, 1996; Bryja M., Piechota niemiecka..., s. 15-19, Sovietu Sąungos - Ленский А. Г., Сухопутные силь РККА в предвоенные годы, справочник, СПб, 2000; Мельтюхов М. И., Советско-польские войныл..., Int. prieiga: http://militera. lib.ru/research/meltyukhov/index.html [žr. 2012-01-22] ir kt.
} 


\section{Baltijos šalių ginkluotųjų pajègų ir prie Baltijos šalių okupacijai sutelktos SSRS kariuomenès sudètis $1940 \mathrm{~m}$. birželi ${ }^{75}$}

\begin{tabular}{|l|c|c|c|c|c|}
\hline & Lietuva & Latvija & Estija & $\begin{array}{c}\text { Baltijos } \\
\text { šalys } \\
\text { kartu }\end{array}$ & SSRS \\
\hline $\begin{array}{l}\text { Pėstininkų ir motorizuotųų šaulių } \\
\text { divizijų }\end{array}$ & 5 & 7 & 4 & 13 & 25 \\
\hline Pėstininkų brigadų & 1 & & & & $1^{77}$ \\
\hline Kavalerijos divizijų & - & & & & 4 \\
\hline Kavalerijos pulkų & 3 & 1 & 1 & 5 & - \\
\hline Tankų brigadų & & & & & 12 \\
\hline Karių & 121000 & 130000 & 132000 & 427000 & 435000 \\
\hline Tankų ir tankečių & $34^{780}$ & 30 & 22 & 86 & 2021 \\
\hline Šarvuotų automobilių & 10 & 7 & 21 & 38 & 411 \\
\hline Iš viso pabūklų ir minosvaidžių $^{79}$ & 652 & 451 & 393 & 1493 & 8000 \\
\hline Lèktuvų & 117 & 128 & 42 & 287 & 1995 \\
\hline
\end{tabular}

Mobilizuotų karių skaičius beveik prilygo sovietų sutelktų karių skaičiui, tačiau Baltijos šalys galejjo suformuoti 2 kartus mažiau divizijų. Labai skyrèsi turètos šarvuotosios technikos, artilerijos ir aviacijos kiekiai.

${ }^{75}$ Lietuvos pajègu sudetis pateikta remiantis ịvairiuose LCVA fonduose saugomais duomenimis, Latvijos ir Estijos - Salo U., Eesti kaitseväe valmisolek sõjaks ..., Sovietų Sąungos - Ленский А. Г., Сухопутные силь РККА в предвоенные годы, справочник, СПб, 2000; Мельтюхов М. И., Упущенньй шанс Сталина. Советский Союз и борьба за Eвpony: 1939-1941, Москва, 2000. Int. prieiga: http://militera.lib.ru/research/ meltyukhov/index.html [žr. 2012-01-22] ir kt.

76 To meto sovietinè motorizuotụjų šaulių divizija gali būti prilyginta šaulių divizijai - ji skyrèsi tik didesniu autotransporto priemonių skaičiumi.

77 214-oji oro desanto brigada pagal savo organizaciją, karių skaičių ir ginkluotę gali būti prilyginta atskirajai pėstininkų brigadai.

78 Neįskaičiuoti 10 lengvųjų tankų VCL, sudegusių 1939 m. lapkričio mėn. kilusio gaisro metu.

79 Visų tipų lauko ir sunkiosios artilerijos pabūklų ir minosvaidžių. Pažymètina, kad tik sovietų istorikai ị bendrą artilerijos skaičių įtraukdavo $45 \mathrm{~mm}$ prieštankinius pabūklus ir $50 \mathrm{~mm}$ minosvaidžius, kurie pagal savo kovinius duomenis negali būti prilyginti lauko artilerijos pabūklams. 
Tačiau sovietiniai tankai buvo itin prastos techninès būklès, lengvai šarvuoti, nedidelių resursų, jų (taip pat ir aviacijos) galimybes veikti gerokai mažino vadovavimo, ryšių, tiekimo ir remonto trūkumai. Pasibaigusiame Žiemos kare sovietinè aviacija, kuriai nebuvo tokių kliūčių kaip sausumos kariuomenei, veikè visiškai neefektyviai ir didžiulè persvara ore neturejjo tokios įtakos, kokios buvo galima tikètis iš tokių didelių oro pajègų ${ }^{80}$.

1940 m. birželị (ir anksčiau) SSRS kariuomenė buvo toks pat milžinas ant molinių kojų, kaip kad Žiemos kare. DVRA dar neturejo naujų tipų ginkluotès, kuria jau disponavo $1941 \mathrm{~m}$. birželi. Be didelio junginių ir ginkluotès kiekio, ne mažiau svarbūs ir kiti veiksniai, kuriuos skaičiais apibrèžti praktiškai neįmanoma. Mūsų nagrinejjamu atveju tai būtų Baltijos šalių kariuomenių galimybès ir pajègumai veikti kartu kitos šalies teritorijoje.

NATO istorija šaltojo karo metais rodo, kiek buvo įdèta pastangų, siekiant kuo labiau standartizuoti ginkluotę, šaudmenis ir kitą karo techniką, ir kokių trūkumų šioje srityje liko iki pat Varšuvos pakto žlugimo. Nemažiau sudètingi buvo vienos NATO šalies kariuomenès veikimo kitos šalies teritorijoje klausimai. Bene daugiausiai buvo nuveikta bendros vadovybès srityje. Pirmą kartą istorijoje buvo sukurta situacija, kai vienos nepriklausomos šalies kariuomenès junginiai ir daliniai galejo pereiti visiškon kitos šalies kariuomenès atstovo valdžion. Ir didžioji dalis esminių laimejjimų šiose srityse buvo pasiekta tik dominuojančios ir konsoliduojančios JAV dèka. Tokio potencialaus vienijančio ir vadovaujančio lyderio Baltijos antanteje nebuvo.

1935 m. Baltijos šalyse buvo pradètos karinès reformos. Jos palietė ginkluotès, taktikos, organizacijos ir kt. sritis. Šias reformas lèmé du esminiai veiksniai: nacizmui įsigalejus Vokietijoje, Sovietų Sąungoje ir Europos šalyse prasidejusios ginklavimosi varžybos bei, antra, pasibaigusi pasaulinè ekonomikos krizè. Lietuvos istoriografijoje 1935 m. reforma tradiciškai siejama su naujuoju Lietuvos kariuomenės vadu paskirtu S. Raštikiu, o pastaruoju metu vis dažniau ir su Lietuvos Respublikos igaliotuoju pasiuntiniu Berlyne K. Škirpa. Tačiau labiausiai Lietuvos, kaip ir kitų Baltijos šalių, kariuomenès reformą, ypač ginklavimosi srityje, sutrukdè 1929-1933 m. pasaulinẻ krizè. Prieš prasidedant šiai krizei

${ }^{80}$ Baltijos šalių ir Sovietų Sąungos karo aviacija bus nagrinejjama atskirame tyrime. 
buvo ịsigyta daug čekiškų lengvųjų kulkosvaidžių, dvi baterijos angliškų patrankų „Vickers Mk IV“. Pasibaigus pasaulinei krizei ir nuvertejus svarui, Lietuvos kariuomené pasinaudojo galimybe pigiau įsigyti ginklų ir kitos karo technikos. 1936 m. atsivèrè visiškai neplanuotas finansavimo šaltinis. Prasidejjus pilietiniam karui Ispanijoje, visų šalių kariuomenės atsikratẻ sandèliuose užsilikusiomis senienomis. Abi kariaujančios pusès, ypač respublikonai, pirko praktiškai bet kokią, net ir mokomąją, karo techniką ir ginklus. Tai sudare prielaidas įsigyti modernios ginkluotès ir gaminti ją patiems.

\section{Ginkluotės ir karo technikos standartizavimas}

Kariuomenès ginkluotès, technikos ir įrangos standartizavimo svarba - neginčijama. Ne mažiau standartizacija reikšminga ir kuriant karinę kelių valstybių sąjungą. Ginkluotos vienodais ginklais ir (arba) naudojančios vienodus šaudmenis bei kitą karinị turtą kariuomenès gali veikti viena kitos teritorijoje, naudodamosi viena kitos sandeliais. Pvz., Lietuvos divizija galètų būti greičiau permesta ị Latvijos ir Estijos teritoriją, nes būtų galima su savimi gabentis mažiau karo veiksmams reikalingo turto. O veikiant kitoje šalyje nekiltų problemų apsirūpinant šaudmenimis ir kt. reikmenimis. Edgaras Andersonas užsimena apie, ko gero, pirmąjł mėginimą standartizuoti Latvijos ir Lietuvos ginkluotųų pajėgų karinị turtą. Dèl to tarèsi britų generolo Arturo Turnerio (Arthur J. Turner) iniciatyva 1920 m. vasarị Valgoje susitikę Lietuvos ir Latvijos kariuomenių atstovai. Tačiau, nepasiekus politinio abiejų šalių susitarimo ${ }^{81}$, jokių veiksmų ginkluotei standartizuoti nebuvo imtasi.

Netgi 1923 m. Estijos ir Latvijos sudarytoje karineje sutartyje nebuvo numatyta ginkluotės standartizacija ${ }^{82}$. Susikloste kurioziška situacija. Latviai estams priekaištavo, kad šie perka vokiškus ginklus, kai įsigyjama Latvijos kariuomenès ginkluotė buvo beveik išimtinai angliška arba naudojanti anglišką amuniciją. Tačiau apie tokius priekaištus žinome tik... iš

${ }^{81}$ Andersons E., The Military situation in the Baltic States // Baltic Defence Review, No. 6, Volume, 2001, p. 123.

82 Žr.: Ильмярв Магнус, Безмолвная капитуляция..., с. 241. 
britų diplomatų susirašinejjimo ir šie priekaištai greičiausiai neturi realaus pagrindo, nes vokiška ginkluotė Estijos kariuomenejje tuo metu sudare tik labai nedidelę dalį.

Prieškariu karabinai, šautuvai, lengvieji ir sunkieji kulkosvaidžiai bei artilerija buvo pagrindiniai ginklai, kurių šaudmenis Baltijos šalių kariuomenèse būtų buvę naudinga standartizuoti. Suvienodinta amunicija būtų leidusi daliniams veikti bet kurioje šalyje, apsirūpinant iš sąjungininko sandèlių. Apie tai buvo kalbama ir tarp Baltijos šalių diplomatų. Pvz., 1936 m. vasario 29 d. Vašingtone vykusiame eiliniame (IV) Baltijos atstovu pasitarime, kuriame dalyvavo Lietuvos nepaprastasis pasiuntinys ir igaliotasis ministras JAV P. Žadeikis bei atitinkamo rango Latvijos atstovas dr. Bilmanis, svarstyta: „2. Baltijos santarvés dalykai. Išsitarta, kad Baltijos santarvè turètų büti pagilinta triju valstiju karinio apsigynimo sutartimis ir kad tam tikslui turètu büti einama prie suvienodinimo ginklavimosi: armotu, aeroplanu, etc. Jūros apsaugai reikalingos povandeninès valtys: estai yra užsakę dvi, taipgi latviai. Nèra žinoma, ar Lietuva yra toki užsakyma padariusi, ar ne." 83

Lietuvos kariuomenė naudojo vieno kalibro šaudmenis - 7,92 mm „Mauser“, Latvijos - 7,7 mm britiškus (.303 British), Estija - dviejų kalibrų: 7,7 mm britiškus ir 7,62 mm rusiškus „Mosin“. Iki šiol ginčijamasi, kuris iš jų buvo geresnis, nes iš esmès visi trys skyrèsi tik tam tikrais parametrais ir buvo vienodai pavojingi, t. y. galejo būti naudojami toms pačioms užduotims atlikti. Be abejo, mažesnei ir daugiau sunkumų apsirūpinant šoviniais patiriančiai šaliai patogu naudoti priešininko šovinius. Suomijos kariai tikrai džiaugèsi, kad visiems suomiškiems šaulių ginklams tiko sovietinių šautuvų šoviniai. Lietuvos kariuomenė galejjo naudoti visus vokiečių ir lenkų kariuomenių šovinius, o Estijos - 7,62 mm sovietinius. Pažymètina, kad šaudmenų tipas buvo pasirinktas labai anksti, ir nebuvo jokių prielaidų, kad Baltijos šalys galètų susitarti unifikuoti savo šaudmenis, kadangi tokio proceso kaina būtų buvusi nepaprastai didelè. Pvz., Lietuvos kariuomeneje 7,92 mm sunkusis kulkosvaidis 08 buvo ¿vertintas 3900 Lt, lengvasis kulkosvaidis „Brno“ 26 m. - 1500 Lt, šautuvas „Mauser“ -125 Lt, o vienas šovinys - 15 ct. 1939 m. rugsèji turètiems 130000 šautuvų ir karabinų pakeisti reikejjo 15 mln., 3700 lengvujų kul-

${ }^{83}$ Kasparavičius A., Lietuva 1938-1939 m. Neutraliteto iliuzijos..., p. 259. 
kosvaidžių - 5,55 mln., 800 sunkiụjų kulkosvaidžių - 3,12 mln., $89 \mathrm{mln}$. šovinių - 13,35 mln., iš viso - apie $37 \mathrm{mln}$. Lt. Sumokèti tokią kainą vien už šaulių ginklų standartizaciją nebūtų ryžusis nė viena Baltijos valstybė, o juk dar buvo ir kitų, brangesnių, rūšių ginklų.

Lauko artilerijos parko priemonių - lengvųjų lauko patrankų ir haubicų - taip pat buvo kelių tipų ir kalibrų. Pagrindinis lauko artilerijos pabūklas Lietuvoje buvo $75 \mathrm{~mm}$ prancūziška, Latvijoje - 83,8 mm britiška, Estijoje - 76,2 mm rusiška patranka. Tačiau visos trys šalys šių tipų pabūklų ir jiems tinkamų sviedinių turèjo nedaug. Sunkiojoje artilerijoje vyravo pabūklų ịvairovė, tačiau Latvija ir Estija turejjo ir vienodo - 107 mm - kalibro sunkiųjų patrankų. Jau Antrojo pasaulinio karo išvakarėse, 1939-1940 m., atsirado reali galimybè suvienodinti artileriją. Tuo metu Latvija ir Estija 1940 m. Vokietijoje užsake 105 ir $150 \mathrm{~mm}$ artilerijos, naudojančios tokius pat sviedinius, įsigijo vienodų $47 \mathrm{~mm}$ prieštankinių pabūklų „Böhler“, Estija dar užsisake $20 \mathrm{~mm}$ vokiškų automatinių pabūklų „Solothurn“, naudojančių tą pačią amuniciją kaip ir lietuvių turimi pabūklai. Baltijos šalims, atsižvelgiant ị politinę situaciją suplanavus ìsigyti didelius naujos ginkluotès kiekius iš likusio vienintelio ginkluotès tiekejjo - Vokietijos, ginkluotès suvienodinimas vyko savaime. Dar reikètų paminèti 81,4 mm minosvaidžius, kurių skaičius ženkliai didejjo ir kurie galèjo naudoti vienodas minas. Baltijos šalyse $1940 \mathrm{~m}$. buvo planuojama gaminti prieštankinius šautuvus ir pabūklus, minosvaidžius ir buvo pagaminti bandomieji pavyzdžiai. Bene blogiausioje padètyje buvo Lietuva, paveldejusi silpniausią ginklų gamybai reikalingą pramonę. Be jokios abejonès, suvienijusios savo pastangas, Baltijos šalys galejo pasidalyti gamybos sritis arba kooperuotis sudedamųjų dalių gamyboje ir pačios apsirūpinti vienodais šautuvais, kulkosvaidžiais, šoviniais, granatomis, prieštankinėmis ir jūrų minomis, minosvaidžiais, prieštankiniais pabūklais ir artilerijos šaudmenimis, gerokai sumažinti išlaidas ir suvienodinti ginkluotę. Daug buvo galima pasiekti ir bendrai apsirūpinant ryšio ir transporto priemonèmis.

Tačiau nèra jokių duomenų, kad būtų bent svarstoma tokia galimybė. Ir tas neturètų stebinti. Netgi vèliau, po Antrojo pasaulinio karo, net nuolatos jaučiančios sovietinio bloko grèsmę Vakarų Europos šalys, nepaisant keleto sèkmingų projektų, dažniausiai nesutardavo dèl bendros ginklų ga- 
mybos. Sunkiausia buvo susitarti dèl kiekvienos atskiros šalies dalies ginklų gamyboje, dèl šalių karo pramonès įmonių indèlio, t. y. ekonominiai ir vidaus politikos veiksniai nusverdavo akivaizdžią būtinybę kooperuotis. Tarpukariu tai padaryti buvo dar sunkiau. Pažymètina, kad kol kas dar nèra atliktas išsamus Lietuvos karo pramonès tyrimas. Kol kas vertinti Baltijos šalių karo pramonės pajėgumus ir galimybes kooperuotis sunku.

Reikètų pažymèti, kad ginkluotès klausimas tikrai nebuvo pats svarbiausias. Baltijos šalys buvo ginkluotos palyginti gerai ir gana moderniais ginklais, kad 1939-1940 m. galètų trumpiau ar ilgiau sėkmingai priešintis SSRS agresijai. Netgi labai anksti susikooperavus ir apsirūpinus didesniais ginklų kiekiais, tai būtų tik mažytis laimejjimas, pasireiškiantis atskirais taktiniais atvejais. Net jeigu būtų turèta kelis kartus daugiau šaunamųjų ginklų ar artilerijos pabūklų, nebūtų padaugèję galimybių atremti milžiniškos Raudonosios armijos puolimą.

\section{Bendra vadovybè ir veiksmai}

Nevienoda ginkluote apsunkino tiekimą, remontą ir aprūpinimą, bet iš esmès netrukdè Baltijos šalių kariuomenèms veikti kartu. Daug sudètingesnis buvo bendrų veiksmų ir vadovavimo klausimas. Rodos, neturètų būti labai sunku pasirinkti principą, kuriuo remiantis būtų paskirtas jungtinių pajègų vadas. Tačiau kaip nustatyti bendrų karinių pajėgų vado kompetencijos ribas? Kaip suderinti Konstitucijoje įtvirtintą principą, kad vyriausiasis kariuomenès vadas yra prezidentas, su bendrų karinių pajègu vado skyrimu? Kaip suderinti krašto apsaugos ministrų, kuriems taikos metu paklūsta kariuomenių vadai, veiklą? Latvijos ir Estijos karinis bendradarbiavimas atskleidè sunkumus, kylančius tiek sprendžiant vadovybès klausimus, tiek ịveikiant kalbos barjerą. Abiejų šalių karinès pajègos liko savo vadovybių rankose. $\mathrm{O}$ mūšio lauke vienodo dydžio dalinių bendriems veiksmams turejjo vadovauti aukštesnio laipsnio karininkas. Jeigu daliniai buvo skirtingo dydžio, vadovauti turèjo einantis aukštesnes pareigas ${ }^{84}$. Rodos, labai paprasta. Tačiau dar buvo kitų veiksnių - amžius, asmeninès savybès, politinè ịtaka šalies viduje. Antrajame pasauliniame kare tarp Va-

${ }^{84}$ Žr.: Ильмярв М., Безмолвная капитуляция..., с. 241. 
karų sąjungininkų, ypač tarp anglų ir amerikiečių vadų, ne kartą kilo labai stipri trintis, kurią teko šalinti ir pačiu aukščiausiu politiniu lygiu.

Kariuomenès vadui reikalingas štabas. Štabui reikalingi karininkai. Pastarieji turi suprasti vienas kitą iš karto ir be jokių abejonių, privalo kalbèti ir mąstyti tais pačiais terminais. Duoti komandas, suprantamas net ir analfabetui kitos šalies kariuomenès kariui. Net ir šiandien, vartojant visuotinai priimtą anglų kalbą, NATO terminus, kodifikaciją, kyla sunkumų. Kaip pažymejjo E. Andersonas, nebuvo bendros lingua franca ${ }^{85}$. Estijos ir Latvijos karineje sutartyje buvo numatyta, kad bus vadovaujama estų ir latvių kalbomis. Vartoti rusų kalbą atsisakyta, kadangi nepriklausomybės metais vis didejjo skaičius karininkų ir karių, šią kalbą mokančių prastai ar visai nemokančių, ir ateityje rusų kalbos igūdžiai turejjo tik prastėti ${ }^{86}$. Dar labiau kalbų klausimas komplikuotųsi prie karinès sąjungos prisijungus trečiajai šaliai. Nekyla abejonių, kad tiek vadovavimas per vertejjus, tiek tinkamų vertẻjų paieška būtų sunkiai sprendžiama problema.

Pažymėtina viena svarbi aplinkybè. Didžioji dalis Latvijos ir Estijos kariuomenès vadovybės karininkų buvo kadriniai carinės Rusijos kariuomenès karininkai, karinị išsilavinimą igiję aukštosiose karo mokyklose. Ne vienas jų dalyvavo 1904-1905 m. Rusijos-Japonijos kare, o Pirmojo pasaulinio karo metais jau buvo išsitarnavę aukštus laipsnius ir ejo vadovaujamas pareigas. Visiškai kitokia padetis buvo Lietuvos kariuomeneje. Dauguma įvairiais tarpukario metais vadovaujamas pareigas ejjusių karininkų karo metais buvo baigę trumpus karininkų rengimo kursus, vadovavę smulkiems daliniams. Šiandien mums galbūt sunku suvokti skirtumą tarp prieškarinių karininkų, elitinės carinès Rusijos klasės atstovų, ir karininkų „iš masių“, paskubomis parengtų jau vykstant pasauliniam karui. Neturètų stebinti ir kiek neobjektyvus bei šališkas J. Laidonerio prielankumas lenkams ir Lenkijai. Gali būti, kad jam ir daugeliui kitų Latvijos ir Estijos karininkų, baigusių Vilniaus pėstininkų karo mokyklą, jaunystėje ittaką padarẻ bendravimas su lenkiška Vilniaus aukštuomene.

Beje, ir diplomatiniuose sluoksniuose būta povandeninių akmenų. Labai įdomus Vokietijos URM VI politinio skyriaus vedejo Grundherio prieš 1937 m. spalio 8 d. vizitą pas valstybès sekretorių pateiktas Latvijos

\footnotetext{
${ }^{85}$ Anderson E., The Military situation in the Baltic States..., p. 146.

86 Žr.. Ильмярв М., Безмолвная капитуляция..., с. 241.
} 
užsienio reikalų ministro V. M. Munterso įvertinimas: „Latvijos užsienio reikalų ministras M. Muntersas, 39 metu amžiaus, vokiečiu kilmès, vedęs rusę $\langle\ldots\rangle$. Keleta kartu jo elgesys parode, kad jo orientacija neabejotinai antibaltiška<... >“87

Dalis Baltijos šalių aukštesniųjų karininkų buvo baigę mokslus tose pačiose užsienio šalių karo akademijose, laisvai kalbejo keletu kalbų. Vis dèlto pokarine ilgamete NATO patirtis rodo, kad reikia nepaprastai daug bendrų pratybų, mokymų, kol skirtingų šalių kariai pradeda veikti darniai, sutartinai. Ir tai pasitaiko daug apmaudžių klaidų, o pats bendradarbiavimas ir mokymas labai brangiai kainuoja. Tačiau ir ši problema buvo išsprendžiama. Sudetingiausias klausimas buvo kitas: kur ir kaip gintis? Ką ginti?

\section{Kaip ir kur gintis}

Einančio užsienio reikalų ministro pareigas K. Bizausko 1939-06-16 atmintinejje užfiksuotas įdomus pokalbis per susitikimą su Estijos pasiuntiniu A. Varma apie Baltijos šalių karinị bendradarbiavimą:

„Tiesa, mes neturime jokiu ịrodymų, tačiau lyg ir peršasi mintis, kad latviai lyg ir spekuliuoja savo geografine padetimi. Formaliai jie laikosi estu-latviu karines sutarties, bet neduoda jai turinio, matyt, galvodami, kad jeigu bus pavojus iš šiaurès rytu, tai pirmiausia jis turètu paliesti Estiją. Kita vertus, darydami aliuziju mums, turbūt turi galvoje, kad esant pavojui iš vakaru mes būsime pirmieji ir tuo pačiu ginsime Latvija. " 88

Prof. Z. Butkus teigia: „Pačios Baltijos šalys neįstengè susitarti dèl karinio bendradarbiavimo, pavyzdžiui, nesutarè, kokios strateginès linijos labiausiai turès büti ginamos. " ${ }^{89}$

Taigi, visos trys šalys turejo savas strategines ribas, svarbias kiekvienos gynybai, ir nẻ viena iš jų neturejjo pakankamai pajègų šioms riboms ginti.

\footnotetext{
${ }^{87}$ 1937-10-07 Brief for Latvian Foreign Minister Munter's visit to the State Secretary for October 8//Documents of Germany Foreign Policy 1918-1945. Series D (1937-1945), Volume V, Document No. 316, US Government printing Office, Washington, 1953, p. 418. ${ }^{88}$ Butkus Z., Baltijos valstybiu vienybès..., dok. Nr. 272, p. 723.

${ }^{89}$ Butkus Z., Vokietijos ir sovietu politikos poveikis..., p. 37-38.
} 
Nè viena iš šalių jokiu būdu negalëjo sutikti, kad jai svarbios strateginès ribos ir teritorija būtų „mažiau“ ginama arba neginama, o jos ginkluotosios pajègos būtų nukreiptos ginti kitą šalị. 1938 m. rugpjūčio 25 d. apsilankiusiam Lenkijos „charge d'affaires“ Zalenskiui Lozoraitis pasakè: „Pakto 16 straipsnis yra pagristas kolektyvinio saugumo principu. Man atrodo, negali būti kalbos, kad šitas principas, ypač mažujų valstybių, palankiai tegali būti traktuojamas, nes paprastas aritmetiškas apskaičiavimas įrodo, jog geriau yra, reikalui esant, prie šimto ar 150 tūkstančiu Lietuvos kareiviu prijungti dar 100.000 kitu kareiviu, kurie mums galètu padèti, negu kad, esant užpultiems, gintis vieniems. ${ }^{"{ }_{90}}$

Šis teiginys nèra visiškai teisingas. Nors bendras karių skaičius būtų 200 ar 250 tūkst., Lietuvos teritorijoje jų vis tiek tebūtų tie patys 100-150 tūkst. Nes situacija, kai kiekviena sąjungos šalis ginasi savo teritorijoje, beveik nesiskiria nuo tos, kai visos trys šalys gintųsi savarankiškai, nesudariusios jokios karinès sąjungos. Teoriškai sujungtos $\mathfrak{i}$ „,vieną kumštị“, kiekvienos iš šalių pajegos būtų priverstos kautis atskirai - kiekviena savo teritorijoje. Taigi vietoje „vieno kumščio“ ir vèl matome tas pačias kariuomenes, besiginančias tomis pačiomis sąlygomis ir tose pačiose ribose.

Kiekvienos Baltijos šalies saugumui pavojingiausios kryptys buvo skirtingos. Šiomis kryptimis einantys keliai leido priešo kariuomenei sparčiai judèti pirmyn ir užtikrinti savo puolančių pajègų aprūpinimą. Šiomis kryptimis buvo puolama ir 1941 m., frontui ritantis ị Rytus, ir 1944 m., raudonajai lavinai veržiantis ị Vakarus.

Pažymètina, kad Latvijos karinis laivynas turejo ginti tik savo pakrantę, o blokuoti Suomių illanką teko vien Estijos kariniam jūrų laivynui, tikintis tik Suomijos, su kuria nebuvo jokio karinio ar politinio susitarimo, laivyno veiksmų Estijos pakrantejje $e^{91}$.

Puolant Vokietijos pajègoms iš Rytų Prūsijos, viena pagrindinių puolimo ašių būtų buvusi Tauragè-Šiauliai-Ryga, antroji - Vilkaviškis-Kaunas-Ukmergè-Daugpilis-Rezeknè.

Prasidejus pilietiniam karui Ispanijoje, Vokietija ir SSRS šioje šalyje

\footnotetext{
${ }^{90}$ Laurinaitis Č., Moderniųjų lietuvių raida nuo kalbinès bendruomenės link teritorinès. XX a. pirma pusè. Cit.: 1938-09-02 Lozoraičio promemoria: Pasikalbejimai dèl Tautu Sąjungos Pakto 16 straipsnio // LCVA, F.648, ap. 1, b. 53, 1. 309.

91 Žr.: Ильмярв М., Безмолвная капитуляция..., с. 243.
} 
stojo ị atvirą kovą. Iškilo vokiečių ir sovietų karo grèsmè. Sovietų karinès vadovybès planuose svarstyta galimybè Rytų Prūsiją pasiekti smogiant per Baltijos šalių teritorijas. Baltijos šalių vaidmenị pridengiant Rytų Prūsiją aptarè ir JAV spauda: „Amerikos spauda pabréžia, kad Baltijos valstybiu neutraliteto strateginé reikšmé yra labai didelé: tos valstybès dengia Vokietijos kairiji sparna nuo Rusijos puolimo, nes rusu armija negali pulti Vokietijos per Lenkijos žemę. " ${ }_{92}$ Šis klausimas buvo toks svarbus sovietams, kad tardomas sovietinis maršalas Michailas Tuchačevskis ji paminejjo net 1937 m. birželio $1 \mathrm{~d}$. duodamas parodymus apklausoje: „Ne [pribaltu] agresija, o pribaltu neutralitetas sutrukde pritaikyti ryžtingiausią plana, ir jis buvo atšauktas ne karinès žinybos, o vyriausybès sprendimu<...> Pribaltu neutralitetas mums labai pavojingas. ${ }^{\text {"93 }}$ Kaip paaiškejo vèliau, Baltijos šalių neutralitetas jokios reikšmės agresyviems SSRS planams neturẻjo.

Tinkamiausia gynybai teritorija teko Estijai. Ypač lengvai ginama buvo riba šiaurès rytuose, nuo Suomių ịlankos iki Peipaus (est. Peipsi) ežero palei Narvos upę. Čia ejo tik vienas kariuomenei tinkamas judèti kelias, gamtinès sąlygos buvo palankios, o pelkèta vietovė - itin patogi gintis. Už keleto kilometrų i vakarus reikejjo kirsti tris Sinimejès (Sinimäe) kalvas, per amžių amžius saugančias kelią Narva-Talinas. Jos suteikẻ pranašumą gynėjams. 1944 m. sovietams prireikè beveik šešių mènesių čia vokiečių i̇rengtai „Tanenbergo“ gynybos linijai pralaužti ${ }^{94}$. Toliau tęsèsi Peipaus ežero pakrantė ir buvo tik $165 \mathrm{~km}$ atviros vietovès iki Latvijos sienos.

Tačiau Estijos gynyba turèjo ir silpną vietą. I pietus nuo jos tęsèsi 296 km Latvijos-SSRS siena, nedengiama jokių stambesnių gamtinių kliūčių. Latvijos kariuomenè buvo nepajègi išlaikyti tokią ilgą ir nepatogią gynybai liniją. Todèl numatè trauktis ị centrinę Latvijos dalį, kur Vidžemès aukštumos, miškų masyvai, Dauguva ir jos intakai sudarè sąlygas organizuoti pozicinę gynybą ${ }^{95}$.

\footnotetext{
${ }^{92}$ Kasparavičius A., Lietuva 1938-1939 m. Neutraliteto iliuzijos..., p. 319.

93 Военный совет при народном комиссаре обороны СССР (1-4 июня 1937 г.). Документы и материалы, Москва, 2008, с. 471.

94 Sjødin, Y. The Blue Hills - Sinimäed, Estonia // The Armourer. 2013, September/ October, No. 119, p. 22.

${ }^{95}$ Žr.: Kuzmins V., Latvijas burnoto speku mobilizacijas un aizsardzibas plani // Militarais apskats, 2009, Nr. 3/4, p. 49-60; Ильмярв М., Безмолвная капитуляция..., с. 245.
} 
Vadinasi, atsitraukdama ị patogesnę gynybos liniją, Latvijos kariuomenè atidengtų sovietų kariuomenei kelią i atvirą Estijos kariuomenès užnugarị. Tačiau ir tokiu atveju kurị laiką būtų ịmanoma išlaikyti pajūriu besidriekiantị kelią ir, priešui spaudžiant, juo atsitraukti ị Lietuvą. O dalị Lietuvos kariuomenès pajègų metus Daugpilio kryptimi, čia būtų galima organizuoti gana tvirtą gynybą. Deja, tokia veiksmų eiga buvo galima tiktai teoriškai. Kaip jau minèta, nė vienos šalies politinė vadovybė negalejjo ir neketino priimti altruistinių sprendimų palikti savo šali, karines pajègas telkiant kitos šalies gynybai.

Tą vaizdžiai demonstruoja ir bendri Latvijos bei Estijos kariuomenių mokymai. Per visą šių dviejų šalių karinès sąjungos laiką buvo surengti tik vieni bendri manevrai 1931 m. ir vieni kariniai žaidimai 1934 m., tačiau jų metu tvyrojo intrigų, nepasitikejjimo ir nepakantumo atmosfera ${ }^{96}$.

Susijungusios ị karinę sąjungą ar ne, visos trys šalys negalejo tikètis laimèti karo. Sutelktais daug pranašesnių potencialaus priešininko pajègų smūgiais, nukreiptais išilgai jų sienų, galèjo būti atkirstos viena nuo kitos. Praradusios bet kokị tiesioginị ryšị, jos taptų trimis lokalizuotais pasipriešinimo židiniais. Tai, per kiek laiko priešo pajègos viena ar net keliomis kryptimis pasiektų Baltijos jūrą, būtų tik laiko klausimas. Atsižvelgę i 1939-1941 m. Raudonosios armijos karinių veiksmų patirtị ir ị pastaraisiais metais publikuotus Rusijos istorikų darbus, paskelbtus naujus archyvinius dokumentus, galime daryti išvadą, kad, nepaisant motorizuotųjų pajegų gausos, dèl menkos šių pajègų ir jų naudojamos technikos kokybès sèkmingai gynybai būtų prireikę daugiau negu kelių dienų. Tačiau baigtis būtų aiški - anksčiau ar vèliau Baltijos antantès pajègos būtų suskaldytos ị atskiras, nesusisiekiančias dalis, o SSRS laivynas galètų blokuoti Baltijos jūros pakrantę.

Visų trijų Baltijos šalių kariuomenès buvo menkai motorizuotos. Tai nebuvo kariuomenių vadovybių klaida ar neapsižiūrèjimas. Tarpukariu nebuvo nei ekonominių, nei techninių galimybių turèti judresnes kariuomenes. Tai padaryti trukdè ir žemas šalių motorizacijos lygis, ir prastas kelių tinklas, ir degalų motorizuotosioms transporto priemonėms stygius. Kaip parodè vèlesni ịvykiai, tankų ir motorizuotieji junginiai gali pulti labai greitai ir pavojingai. Reikia pažymėti, kad ir tankų veiksmai sèkmingi tik tada, kai jie naudojami masiškai ir kartu su motorizuotaisiais pėstininkais, arti-

${ }^{96}$ Žr.: Ильмярв М., Безмолвная капитуляция..., с. 243. 
lerija, yra remiami aviacijos. Svarbiausia, kad tankai turi veikti ị gylį, smūgiuoti i sparnus, apeiti, atkirsti puolančią ar besiginančią priešo grupuotę ir veržtis tolyn, ì neapsaugotą operatyvinę erdvę. Sovietų tankų daliniai to padaryti nesugebejo. Net ir nesutikę pasipriešinimo, sovietiniai tankai per dieną íveikdavo apie $40-50 \mathrm{~km}^{97}$. Dèl net ir prastai organizuoto pasipriešinimo, pvz., Vilniuje ir Gardine, tankai patirdavo nuostolių ir būdavo priversti laukti 1-2 dienų žygio atstumu atsilikusių pėstininkų ir kavalerijos. Laiku nepristatyti degalai ir nedidelès gamtinès kliūtys tankų kolonas sustabdydavo vienai dviem paroms. Žiemos karas pademonstravo sovietų kariuomenès inertiškumą ir iniciatyvos stoką. Galima teigti, kad, nepaisant plètojamos "gilaus mūšio" teorijos, sovietų kariuomenè nebuvo pajėgi vykdyti greitų tankų ir motorizuotujų dalinių puolimų i operatyvinę gilumą. Dèl šios priežasties, nors ir esant dideliam kiekybiniam pranašumui, jungtinès Baltijos šalių pajègos turejjo galimybę organizuotai pasipriešinti ir pasitraukti ị trečiosios, karo veiksmuose nedalyvaujančios, šalies teritoriją.

Vengdamos sudaryti karinę sajungą su Lietuva, Latvija ir Estija prarado galimybę išgelbèti savo vyriausybes ir dali gyventojų nuo represijų, jiems traukiantis ị Lietuvą ir prireikus ị Vokietiją. Ivairiuose šaltiniuose minima, kad, Latvijos prezidentui Ulmaniui paklausus apie galimybę kariuomenei pasitraukti ị Vokietiją, buvo gautas neigiamas atsakymas. Tačiau reikia skirti atsargų atsakymą $\mathfrak{i}$ abstraktų klausimą ir realią padètị, kai prie sienos stovi besitraukianti kariuomenè ir pabėgèliai. Juk Vokietija sovietams neišdavė nei prezidento A. Smetonos, nei kurio nors kito nuo okupacijos pabėgusio asmens. Atsižvelgiant i Vokietijos ir SSRS santykius ir nepanaikinamus ideologinius prieštaravimus, Vokietija, prisidengdama tarptautinèmis sutartimis, negalejo neinternuoti besitraukiančios kariuomenès ir vyriausybių, kurios ateityje galejo tapti svarbia korta politiniame žaidime su sovietais. Tokia padètis atsispindi ir Vokietijos užsienio reikalų ministerijos bei ginkluotujų pajègų vadovybès dokumentuose. Naktị iš 1940 m. birželio 15-osios ị 16-ąją budintis Užsienio reikalų ministerijos pareigūnas informavo, kad Lietuvos prezidentas A. Smetona su lydinčiais asmenimis pasiruošęs pereiti sieną, kad tikimasi sulaukti ir sovietų ultimatume paminètų buvusio vidaus reikalų mi-

\footnotetext{
${ }^{97}$ Plačiau žr.: Гарсия X. В., Бронетанковые операции Второй мировой войны, Москва, c. 11-17.
} 
nistro K. Skučo, ir Valstybės saugumo departamento vadovo A. Povilaičio ${ }^{98}$. Tuo pat metu abvero Karaliaučiaus skyrius pranešè, kad prezidentas A. Smetona, 3 val. pasitraukęs ị Vokietiją, davè ịsakymą Marijampoleje ir Taurageje dislokuotiems pulkams. Vyriausioji ginkluotųjų pajėgų vadovybė (OKW) kreipèsi ị užsienio reikalų ministrą J. Ribbentropą, prašydama nurodymų, kaip elgtis Lietuvos kariuomenès daliniams pasiekus Vokietijos sieną ${ }^{99}$. Vokietijos užsienio reikalų ministras atsake $\dot{e}^{100}$ :

„1. Aš jau daviau nurodymus gestapui internuoti Lietuvos prezidentą Smetoną, jo šeimą ir kitus „žaliąją sieną“ perèjusius pareigūnus.

2. Jeigu Lietuvos kariuomenès daliniai paprašys leidimo kirsti Vokietijos sieną, toks leidimas jiems gali būti duotas. Daliniai turi būti nuginkluoti ir internuoti.

3. Buvo pranešta, kad Lietuvos pulkininkas pasisiūlè su savo pulku pereiti sieną. Lietuvos karius, kurie galimai pereis sieną, turi nuginkluoti ir internuoti ginkluotosios pajègos, bendradarbiaudamos su pasienio policija. Vadovaudamasis susitarimu su valstybès policija, prašau imtis visų reikiamų priemonių, kad būtų nedelsiant informuoti reikiami pasienio postai.

Dar kartą pabrèžiu, kad sieną galima leisti pereiti tik paprašius lietuviams, o mes, savo ruožtu, niekaip neturime skatinti tokių prašymų. Apie tokius atvejus [kaip galima suprasti, su internuotais lietuviais - E. P.] turi būti nedelsiant, pačiu greičiausiu būdu, žodžiu ar raštu, pranešta Vyriausiajai ginkluotujų pajègų vadovybei, prašant tolesnių nurodymų.

Ribbentropas

Pastaba

Vadovaujantis nurodymu, nedelsiant perduota Vyriausiajai ginkluotụjų pajègų vadovybei. Kartu Vyriausioji ginkluotųjų pajègų vadovybé paprašyta apie kiekvieną atvejị, kai Lietuvos kariuomenès daliniai kerta

${ }^{98}$ Division for Political Affairs, Night Duty Officer Welck. The German Foreign Office to the Reich Foreign Minister. Teletype. Berlin, June 16, 1940//Nazi-Soviet relations. Documents from the Archives of the German Foreign Office. US Department of State, 1948, p. $149,150$.

${ }^{99}$ Foreign Office Memorandum. Berlin, June 16, 1940 // Nazi-Soviet relations..., p. 150. ${ }^{100}$ Kadangi dokumentas Lietuvoje greičiausiai nèra publikuotas, pateikiamas jo visas vertimas. Būtina pažymėti, kad dokumentas iš vokiečių kalbos išverstas ị anglų, o verčiant iš anglų ị lietuvių, gali būti netikslumų. Vertimas autoriaus. 
sieną, nedelsiant informuoti Užsienio reikalų ministeriją.

Heydenas Rynschas ${ }^{101}$

Ivedus ị Baltijos šalis sovietinius kontingentus, padètis kardinaliai pasikeitè. Vienintelè Lietuva išsaugojo galimybę internuotis Vokietijoje. O Latvijos kariuomenè ir vyriausybè buvo izoliuotos nuo Lietuvos, $\mathfrak{i}$ ją vedančius kelius patikimai dengiant sovietiniams tankų daliniams.

Tačiau net ir esant tokiai palankiai dislokacijai, SSRS Baltijos šalis okupavo po vieną, vieną po kitos - pirmiausia užèmé Lietuvą ir taip galutinai atkirto visus atsitraukimo kelius.

\section{IŠVADOS}

Nepriklausomybės kovų metu Baltijos šalių sajunga buvo itin pageidautina ir jos buvo aktyviai siekiama. Karinis veiksnys buvo itin svarbus. Labiausiai destabilizuojančia ir sąjungą sudaryti trukdančia aplinkybe tapo Lietuvos ir Lenkijos tarpusavio santykiai. Vèliau, ịtampai atslūgus, karinis veiksnys prarado savo reikšmę. Iki Miuncheno susitarimo pernelyg pasitikèta tarptautiniais saugumo mechanizmais ir karinès Baltijos sąjungos galimybės nebuvo svarstomos aukščiausiu politiniu lygiu. SSRS jèga privertus pasirašyti tarpusavio pagalbos sutartis ir priimti sovietinès kariuomenès kontingentus, buvo užkirstas kelias sudaryti karinę sąungą. Mègindamos neprovokuoti SSRS ir visiškai neprarasti valstybingumo, Baltijos šalys nesiemė jokių veiksmų, kad sudarytų karinę sąjungą ir bendrai pasipriešintų sovietinei okupacijai. Jungtinès Baltijos šalių karinès pajègos negalejo atgrasyti agresorių ir apsaugoti nuo sovietų okupacijos. Tačiau tokia karinè sąjunga būtų sudariusi sąlygas pasipriešinti agresijai, leidusi pasitraukti vyriausybėms ir daliai gyventojų ir taip išvengti sovietinių represijų. Baltijos šalių karinis potencialas iki pat Lenkijos sutriuškinimo leido kartu pasipriešinti galimam agresoriui. Žvelgiant iš $1940 \mathrm{~m}$. okupacijos perspektyvos, jungtinès Baltijos šalių kariuomenès turèjo galimybę organizuotai pasipriešinti ir pasitraukti i Vokietiją.

101 The Reich Foreign Minister to the German Foreign Office, Berlin, June 16, 1940, 11:15 a. m. // Nazi-Soviet relations..., p. 151. 
Karinis veiksnys galejo tapti įrankiu kuriant ir igyvendinant bendrą gynybos politiką. Tačiau nè vienos iš Baltijos šalių politinè valdžia dèl vidinių procesų, išorinių veiksnių ir kitų aplinkybių neįvertino tokio politinio įrankio reikšmės ir nesièmé valingų veiksmų, kad jis būtų sukurtas.

Iteikta $2013 \mathrm{~m}$. rugsèjo $27 \mathrm{~d}$. 


\title{
L'IMPORTANCE DES FACTEURS MILITAIRES POUR LA CREATION DE L'UNION DES PAYS BALTES
}

\author{
Egidijus PAPEČKYS
}

La Lituanie, la Lettonie et l'Estonie ont senti le danger dès la déclaration de leur indépendance. Pour les trois pays le danger provenait de la Russie Soviétique devenue plus tard Union Soviétique et de l'Allemagne. Il était donc logique que naisse dans les pays Baltes une réflexion à se réunir ensemble. Ainsi, plusieurs possibilités pour la Lituanie, la Lettonie et l'Estonie ont été discutées. Une union, le plus souvent appelée l'Union des pays Baltes ou l'Entente Baltique a été créée seulement en 1934. Un des composants pour une union efficace concernait le facteur militaire. Dans ce cas précis, il faut comprendre le terme facteur militaire comme tout danger d'incursion de forces militaires extérieures, tout besoin intérieur des pays et leurs possibilités à résister ensemble à tout type de danger ou à dissuader tout type d'agresseur. Mais l'Entente Baltique n'avait pas ce composant habituel pour ce type d'union.

Entre 1919 et 1920, il y avait urgence à créer l'Union Baltique en centrant un accord sur le facteur militaire. Malheureusement, la Lituanie de manière involontaire est devenue le maillon faible qui n'a pas permis de créer une telle union. Quand des soldats de l'Armée occidentale des volontaires ont menacé d'étouffer dans son embryon l'indépendance de la Lettonie, celle-ci n'a reçu de l'aide que de l'Estonie. Et encore, cette aide nétait pas très importante. La Lituanie se trouvait entre l'Allemagne, qui soutenait l'Armée occidentale des volontaires, et les forces principales de l'Armée occidentale des volontaires, elle était ainsi coupée par le chemin de fer contrôlé par les forces militaires de l'Armée occidentale des volontaires et des Allemands, la Lituanie était en quelque sorte entre le marteau et l'enclume. En même temps, la politique agressive de la Pologne était un véritable danger pour la Lituanie. L'idée d'un pays commun proposée par la Pologne était un danger réel pour l'indépendance de la Lituanie et l'identité même de la nation lituanienne.

Les relations entre la Pologne et la Lituanie, la politique active agressive de l'Allemagne et de l'Union soviétique ont entravé pendant une longue 
période le processus de la création de l'Union Baltique. Croyant à tort que les pays de l'Entente, et plus tard la Société des nations étaient une garantie qui pouvait assurer une coexistence pacifique en Europe, l'importance des facteurs militaires a donc été diminué. De plus, le pouvoir des agresseurs potentiels nétait pas très grand : par le traité de Versailles les forces armées allemandes étaient limitées et ne constituaient pas un risque, quant aux forces armées de l'Union soviétique, celle-ci sortait juste d'une misère noire après la révolution, d'un désordre bolchevique et d'un important retard technique. Or la coopération militaire entre les pays Baltes ne s’est pas réalisée.

En 1933, quand en Allemagne les nationalistes socialistes ont pris le pouvoir, la situation a changé, une course à l'armement a commencé. Les pays Baltes sont devenus lobjet de discussions des grands pays concernant leurs garanties de sécurité. Jusqu'aux Accords de Munich, comme ils avaient confiance dans les mécanismes internationaux de sécurité, la possibilité d'une union baltique militaire n'avait pas été discutée en haut lieu politique. L'URSS quant à elle a obligé par la force à signer les accords d'aide mutuelle et d'accepter des contingents de l'armée soviétique, ainsi toute possibilité de réaliser une union militaire a été empêchée.

La Lituanie, la Lettonie et l'Estonie n'ont pas essayé de standardiser leurs munitions, n’ont pas planifié d'actions militaires communes ou la possibilité d'avoir une administration militaire commune. Lanalyse des batailles hivernales et de la deuxième guerre mondiale dans les territoires des pays Baltes permet de dire qu'il était possible de résister à l'occupation soviétique par la force militaire. Même si les forces soviétiques étaient en avantage numérique, les forces communes des pays Baltes avaient une possibilité de résister et de se retirer sur le territoire de pays tiers qui ne participaient pas aux actions militaires, en permettant de sauvegarder les gouvernements et en protégeant une partie des habitants des répressions.

Le pouvoir militaire fut le seul moyen politique qui ne fut pas utilisé pour éviter l'occupation ou diminuer ses effets. 


\title{
SIGNIFICANCE OF MILITARY FACTOR FOR THE CREATION OF BALTIC UNION
}

\author{
Egidijus PAPEČKYS
}

The threat to the independence of Lithuania, Latvia and Estonia was caused as soon as they declared it. Possible aggression by Soviet Russia, which later became the Soviet Union, and Germany, posed a danger to all three countries. It was reasonable that the Baltic countries discussed the possibility of getting together. Lithuania, Latvia and Estonia considered various options to form some kind of union. Such a union, often referred to as the Baltic Union or Baltic Entente, was formed only in 1934.

The military factor is one of the components of any effective union. In this particular case it should be understood as the threat of invasion by external military forces, the internal demand and opportunities of the Baltic countries to confront this threat together and deter aggressors. However, the Baltic Entente failed to have this kind of military alliance usual for such type of agreements.

The greatest need to form the Baltic Union, where the main subject of the contract could become the military factor, was in 1919-1920. Unfortunately, through no fault of its own, Lithuania was the weak link that prevented the formation of such a union. Bermondtists threatened to suppress the statehood of Latvia in its infancy and only Estonia provided support. However, it was small-scale support. For Lithuania between Germany supporting Bermondtists and basic Bermondtist forces intersected by the railway artery controlled by the Bermondtists and German Armed Forces was like being between a hammer and an anvil. At the same time, Lithuania was threatened by the aggressive policy of Poland. The idea of the general state offered by Poland was a real threat not only to the statehood of Lithuania, but also to the identity of the Lithuanian nation.

Relations between Poland and Lithuania, the active instigator policy of Germany and the Soviet Union, hindered the formation of the Baltic Union for a long time. Mistakenly believing that the Entente Powers, and later - the League of Nations, was the guarantor of a peaceful co-existence in Europe significantly decreased the importance of the military factor. In 
addition, the military power of potential aggressors was poor: the German armed forces were limited by the Versailles Treaty and did not pose a threat, and the Soviet Armed Forces were trying to escape from post-revolutionary poverty, Bolshevik chaos, and being technically backward. Thus, Baltic military cooperation failed to take place in practice.

In 1933, when the National Socialists took power in Germany, the situation changed, and the arms race began. The Baltic countries became the subject of debates of the major countries on security guarantees. Before the Munich Agreement, international security mechanisms were relied on too much and the possibilities of a military Baltic Union had not been discussed at the highest political level. When the Soviet Union was forced to sign the mutual aid agreements and accept contingents of Soviet troops, the formation of a military alliance was prevented.

Lithuania, Latvia and Estonia neither tried to standardise their weapons nor plan joint military actions and the possibility of joint military command. Analysis of actions during the Winter War and the Second World War in the Baltic countries suggested that it was possible to resist the Soviet occupation by military force. Although there was great advantage in numbers, joint forces in the Baltic countries had the opportunity of organised resistance and retreat into the territory of a third country, not involved in hostilities, allowing governments to be preserved and protecting part of the population from repression.

Military power was the only political instrument that was not used in order to avoid the occupation or reduce its impact. 